\title{
O BULLYING NO CONGRESSO NACIONAL BRASILEIRO: UMA ANÁLISE DO CONJUNTO DE PROPOSTAS LEGISLATIVAS EM TRAMITAÇÃO SOBRE A TEMÁTICA DA VIOLÊNCIA FISICA E PSICOLÓGICA EM ESPAÇOS ESCOLARES
}

\section{THE BULLYING IN THE BRAZILIAN NATIONAL CONGRESS: AN ANALYSIS OF THE SET OF LEGISLATIVE PROPOSALS ON PROCESSING CONCERNING THE THEME OF PHYSICAL AND PSYCHOLOGICAL VIOLENCE AT SCHOOL SPACES}

Katerina Volcov ${ }^{1}$

\section{RESUMO}

Trata-se de uma pesquisa documental em que se objetiva apresentar as proposições legislativas concernentes ao tema do bullying que tramitam nas duas casas legislativas federais e como elas dialogam com a atual legislação no que se refere à educação de crianças e adolescentes. Foi realizada coleta de proposições legislativas nas bases de dados dos sites da Câmara dos Deputados e do Senado Federal a partir de duas palavras-chave: bullying e violência escolar. Foram encontradas 28 propostas legislativas em tramitação na atual legislatura da Câmara dos Deputados e nenhuma em tramitação no Senado Federal. Para efetuar a análise das proposições foram criadas seis categorias: formação, mudanças na LDB, informatização, sensibilização, responsabilização e penalização. Como resultados, obtivemos que: a categoria sensibilização esteve presente em 18 dos 28 PLs, e a atual legislação contempla a implementação de campanhas de sensibilização à população; os PLs da categoria 'formação' e 'mudanças na LDB', por sua vez, não oferecem novos conteúdos jurídicos; no quesito informatização, a lei vigente que institui o Programa de Combate à Intimidação Sistemática (bullying) informa que os Estados e Municípios deverão produzir relatórios das ocorrências, no entanto, não há monitoramento desse item nas políticas públicas estaduais e municipais, consequentemente, não há dados federais sobre a prática; e os 12 PLs contemplados nas categorias 'responsabilização' e 'penalização' buscam incluir o bullying como ato infracional e/ou crime a depender da idade do/ da praticante de intimidação sistemática.

PALAVRAS-CHAVE: Bullying. Violência escolar. Legislação. Crianças. Adolescentes.

\section{ABSTRACT}

It is a documentary research that aims to present the legislative proposals concerning the subject of bullying that are processed in the two federal legislative houses and how they dialogue with the current legislation regarding the education of children and adolescents. A collection of legislative proposals was carried out in the databases of the House of Deputies and the Federal Senate, using two key words: bullying and school violence. There were 28 legislative proposals in progress in the current legislature of the House of Deputies and none in progress in the Federal Senate. In order to carry out the analysis of the propositions, six categories were created: training, changes in $L D B$, reporting, sensitivity, accountability and penalization. As results, we obtained that: the sensitivity category was present in 18 of the 28 PLs, and the current legislation contemplates the implementation of awareness campaigns to the population; the PLs of the category 'training' and 'changes in LDB', in turn, do not offer new legal content; in the area of reporting, the current law that establishes the Bullying Program informs that States and Municipalities must produce reports of occurrences, however, there is no monitoring of this item in state and municipal public policies, consequently there is no federal data on practice; and the 12 PLs in the categories 'accountability' and 'penalization' seek to include bullying as an offense and / or crime depending on the age of the perpetrator of systematic bullying.

KEYWORDS: Bullying. School Violence. Legislation. Children. Adolescents.

1 Pós-Doutoranda em Educação pelo Programa de Pós-Graduação em Educação da Universidade Federal de São Paulo; Doutora em Ciências pela Universidade de São Paulo e professora convidada do curso de Especialização em Psicopatologia e Saúde Pública da Faculdade de Ciências Médicas da Santa Casa de São Paulo. 


\section{Introdução}

Conceitualmente, segundo Olweus (2011, p.151), pioneiro nos estudos sobre o fenômeno denominado bullying, este envolve três critérios para ser definido: "é (1) um comportamento negativo que (2) tipicamente ocorre com alguma repetitividade e é (3) dirigido contra uma pessoa que tem dificuldade em se defender", tendo como pressuposto uma assimetria na relação de poder (OLWEUS, 1993, 1997, 2013), violando os direitos de outro ser humano.

Por envolver violência física e/ou psicológica, o bullying tem preocupado governos, sociedade civil, famílias, intelectuais e pesquisadores, seja para a compreensão do fenômeno, seja para coibir suas manifestações. No Brasil, ainda que crescentes, os estudos a respeito do bullying são recentes e visam, principalmente, o contexto escolar (FANTE, 2005; LOPES NETO, 2005; FRANCISCO, 2009; RISTUM, 2010).

Em âmbito governamental, vale mencionar também as edições de 2009, 2012 e 2015 da Pesquisa Nacional de Saúde do Escolar - PeNSE - , desenvolvida a partir do convênio entre o Instituto Brasileiro de Geografia e Estatística (IBGE) e o Ministério da Saúde (MS), com o apoio do Ministério da Educação (MEC). A PeNSE também contemplou questões a respeito do bullying, mesmo que em suas duas primeiras edições (IBGE, 2009; 2012) as palavras empregadas para entendimento do termo fossem "esculachar, zoar, mangar, intimidar e caçoar" (IBGE, 2015, p.71). Por sua vez, na edição de 2015, em que quase 113 mil estudantes $^{2}$ de todo o país responderam sobre as mesmas perguntas das pesquisas anteriores (e respectivos verbos acima mencionados), houve uma questão específica sobre bullying. Os resultados apresentaram que: $7,4 \%$ dos escolares brasileiros afirmaram que na maior parte do tempo ou sempre se sentiram humilhados por provocações, não havendo uma diferença acentuada entre estudantes do sexo masculino $(7,6 \%)$ e feminino $(7,2 \%)$; o percentual de escolares que se sentiram humilhados oriundos de escolas públicas foi de $7,6 \%$, enquanto o de escola privada foi de $6,5 \%$; e a Região Sudeste foi a que apresentou o maior percentil $(8,3 \%)$

2 Foram analisados e validados questionários de duas amostras: uma com 102.072 estudantes de $9^{\circ}$. ano do Ensino Fundamental, e outra com 10.926, de escolares com idades entre 13 e 17 anos (IBGE, 2015, p.16) entre todas as regiões. O Estado de São Paulo (9\%) foi o estado com o maior percentual de escolares frequentando o $9^{\circ}$ ano do ensino fundamental por frequência que se sentiram humilhados por provocações de colegas da escola nos 30 dias anteriores à pesquisa, por sexo e dependência administrativa da escola, seguido do Paraná $3(8,8 \%)$, Mato Grosso do Sul $(8,4 \%)$, Mato Grosso do Sul $(8,4 \%)$ e Goiás $(8,3 \%)$.

Considerado um problema de saúde pública como alguns e algumas pesquisadoras apontam (IBGE, 2015; MELLO et al, 2017; SILVA et al, 2017), para além dessa perspectiva, entendemos que o bullying é uma questão social complexa e deve ser compreendido de modo sistêmico, visto que ademais dos aspectos de saúde envolvidos, com custos para toda a sociedade, engloba sociabilidades, fatores emocionais e ambientais, família, aspectos econômicos, entre outros, e que ocorre em espaços de socialização e não apenas em espaços escolares, ainda que boa parte das notícias que tratam do assunto, principalmente quando ocorrem crimes e atos infracionais ${ }^{4}$ de intensa e imensa gravidade perpetrados por jovens e adolescentes como foi o caso de Realengo (RJ) e de Suzano (SP), aconteçam dentro de escolas. Nessas duas tragédias, o bullying tem sido apontado como uma das causas pelas quais os jovens atiradores praticaram tais atos, causando a morte de dezenas de pessoas (ADORNO, 2011; UOL, 2011; BARONE, 2019; CORREIO BRAZILIENSE, 2019).

Foi a partir do ocorrido em abril de 2011, no bairro de Realengo, na cidade do Rio de Janeiro, que legisladores federais passaram a criar mais proposições legislativas com o objetivo de impedir novos episódios dessa natureza. Até então, haviam sido apresentadas quatro propostas na Câmara dos Deputados: duas em 2009 e duas em 2010. Em 2011, foram apresentadas 20 proposições legislativas nessa mesma casa. Qua-

3 Esses dados não constam do Relatório Geral da PeNSE 2015. Para tanto, é necessário acessar os dados da tabela Amostra 1, item 1.09 (Situações em Casa e na Escola), , tabela 1.1.9.7, em separado. As informações estão disponíveis em: < https:// www.ibge.gov.br/estatisticas-novoportal/sociais/saude/9134pesquisa-nacional-de-saude-do-escolar.html?=\&t=resultados $>$.

4 No caso de Suzano (SP), pelo fato de um dos autores do massacre ser um adolescente, com base em nossa legislação atual (Constituição Federal de 1988, Estatuto da Criança e do Adolescente (Lei No.8.069, de 13 de julho de 1990) e Lei do SINASE (Lei No. 12.594, de 18 de janeiro de 2012), ainda que existam requintes de crueldade no cometimento de uma ação com fins de morte, o termo jurídico correto para designação é ato infracional. 
tro anos depois, foi sancionada pela presidenta Dilma Rousseff a Lei No. 13.185, de 6 de novembro de 2015, que institui o Programa de Combate à Intimidação Sistemática (Bullying) e, em 2018, pelo seu substituto, Michel Temer, após o golpe de 2016, a Lei No.13.663, de 14 de maio de 2018, que altera o artigo 12 da Lei de Diretrizes e Bases (LDB) da educação nacional, incluindo a promoção de medidas de conscientização, de prevenção e de combate a todos os tipos de violência e a promoção da cultura de paz entre as incumbências dos estabelecimentos de ensino.

Este artigo objetiva apresentar as proposições legislativas concernentes ao tema do bullying que tramitam nas duas casas legislativas federais - Câmara dos Deputados e Senado Federal -, suas respectivas justificativas e como elas dialogam com a atual legislação em vigor no que se refere à educação, promoção e defesa de direitos de crianças e adolescentes, em espaços escolares.

\section{Metodologia}

Realizou-se uma pesquisa documental nos sites da Câmara dos Deputados e no Senado Federal, por meio de seus websites www.camara.leg.br e https:// www25.senado.leg.br, respectivamente, para saber quantas e quais são as proposições legislativas que tramitam na Câmara dos Deputados e Senado Federal a respeito do bullying, em especial, com foco na proteção da infância e da adolescência.

No portal da Câmara, tem-se uma aba denominada "Propostas Legislativas"; no Senado, por sua vez, "Projetos e Matérias". Em cada uma delas, podese optar pela pesquisa simplificada ou avançada. Em nosso caso, optamos pela pesquisa avançada, pois pode-se optar pelas proposições ativas ou em tramitação. Esse modelo de busca avançada possibilita que o usuário dos portais escolha o período de busca, em intervalos, decidindo data, mês e ano de início e término da pesquisa.

Já no portal da Câmara dos Deputados, é possível realizar a pesquisa: pelo tipo da proposição: Proposta de Emenda à Constituição (PEC); Projeto de Lei Complementar (PLP); Projeto de Lei (PL); Medida Provisória (MPV); Projeto de Lei de Conversão (PLV); Projeto de Decreto Legislativo (PDC); Projeto de Re- solução (PRC); Requerimento (REQ); Indicação (INC), etc); por qual órgão foi recebida (plenário; mesa diretora; comissões, etc); pela data de apresentação; pelo tipo de situação (se está em tramitação; se não está em tramitação; ou todas que foram apresentadas); pelo assunto (palavra-chave); pelo autor; pelo partido do autor; pela UF do autor; pelo nome do relator, entre outros itens.

A fim de saber o montante de proposições legislativas em cada casa, a busca das propostas em tramitação deu-se por meio das palavras-chave bullying e violência escolar. O segundo termo foi utilizado para verificar se as e os parlamentares brasileiros utilizam os vocábulos como sinônimos e se havia repetição de matérias legislativas com palavras-chave distintas. Não foram inseridas a data de início, nem de término da busca, pois visou-se obter um cenário completo do que as casas legislativas federais têm proposto na temática. No caso específico da Câmara dos Deputados, para além das palavras-chave, optou-se definir os tipos de proposição da pesquisa. Foram selecionadas: Proposta de Emenda à Constituição (PEC); Projeto de Lei Complementar (PLP); Projeto de Lei (PL); Medida Provisória (MPV); Projeto de Lei de Conversão (PLV); Projeto de Decreto Legislativo (PDC); e, Projeto de Resolução (PRC). Os demais tipos como requerimentos e indicações não forneceriam novas ou mais informações substanciais sobre as proposições legislativas que tramitam.

Desse modo, contatou-se que o Senado Federal $^{5}$ não possui proposições legislativas ativas sobre bullying ou violência escolar. Por sua vez, a Câmara dos Deputados conta com 23 propostas (Tabela 1) quando utilizada a palavra-chave bullying, sendo que nos dois primeiros meses de 2019, na atual $56^{\mathrm{a}}$. Legislatura (2019-2023), já foram apresentadas duas novas matérias e quando utilizado o termo violência escolar na busca, foram encontradas mais 13 proposições (Tabela 2 ).

Com as duas listas de proposições legislativas, a partir da busca pelas palavras-chave, excluíram-se os projetos de lei que se repetem (PL 350/2011, PL 1494/2011, PL 9243/2017 e PL 10162/ 2018) e foram totalizadas 32 propostas legislativas em tramitação.

A partir desse montante, foi realizada a leitura da ementa e o inteiro teor de cada um desses projetos

5 Em 22 de março de 2019 foi realizada a última busca no portal do Senado Federal seguindo a metodologia apresentada. 
de lei a fim de verificar se o texto proposto relacionavase diretamente com o tema do bullying.

Na leitura das propostas observou-se que sete proposições não estavam diretamente relacionadas à temática, ainda que reverberem a defesa e a proteção de pessoas, principalmente, mulheres e pessoas em situação de vulnerabilidade. Assim, foram re- tiradas da análise do material, os seguintes Projetos de Lei: PL 2057/1991; PL 5689/2009; PL 6010/2013; PL 4507/2016; PL 4620/2016; PL 8599/2017 e PL 852/2019. Com a retirada dessas matérias, a lista de proposições legislativas referentes ao tema do bullying passou a contar com 25 projetos de lei para análise.

Tabela 1- Proposições Legislativas - palavra-chave "bullying"6

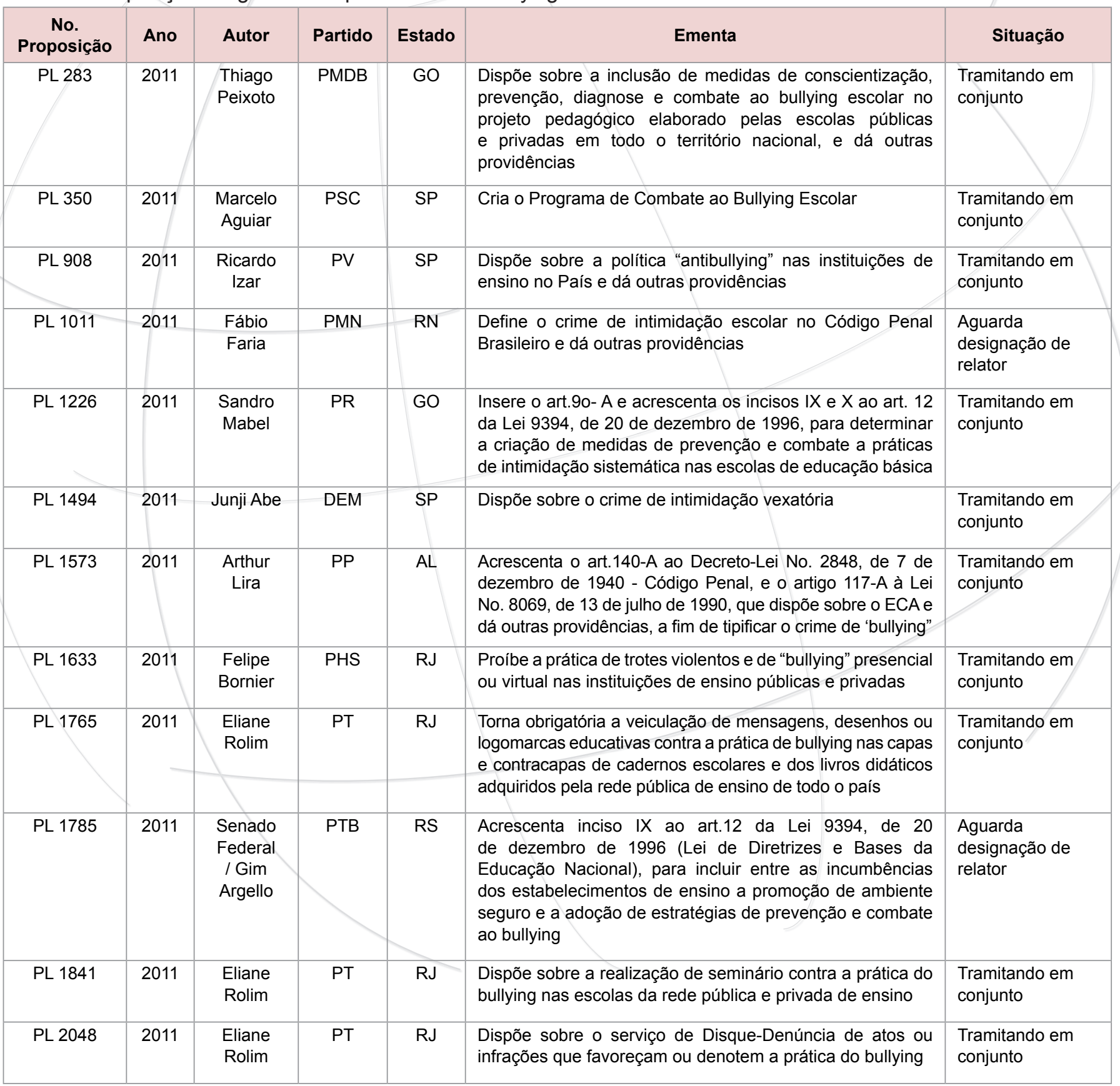

6 Em 22 de março de 2019 foi realizada nova e última busca no portal da Câmara dos Deputados seguindo a metodologia apresentada. 


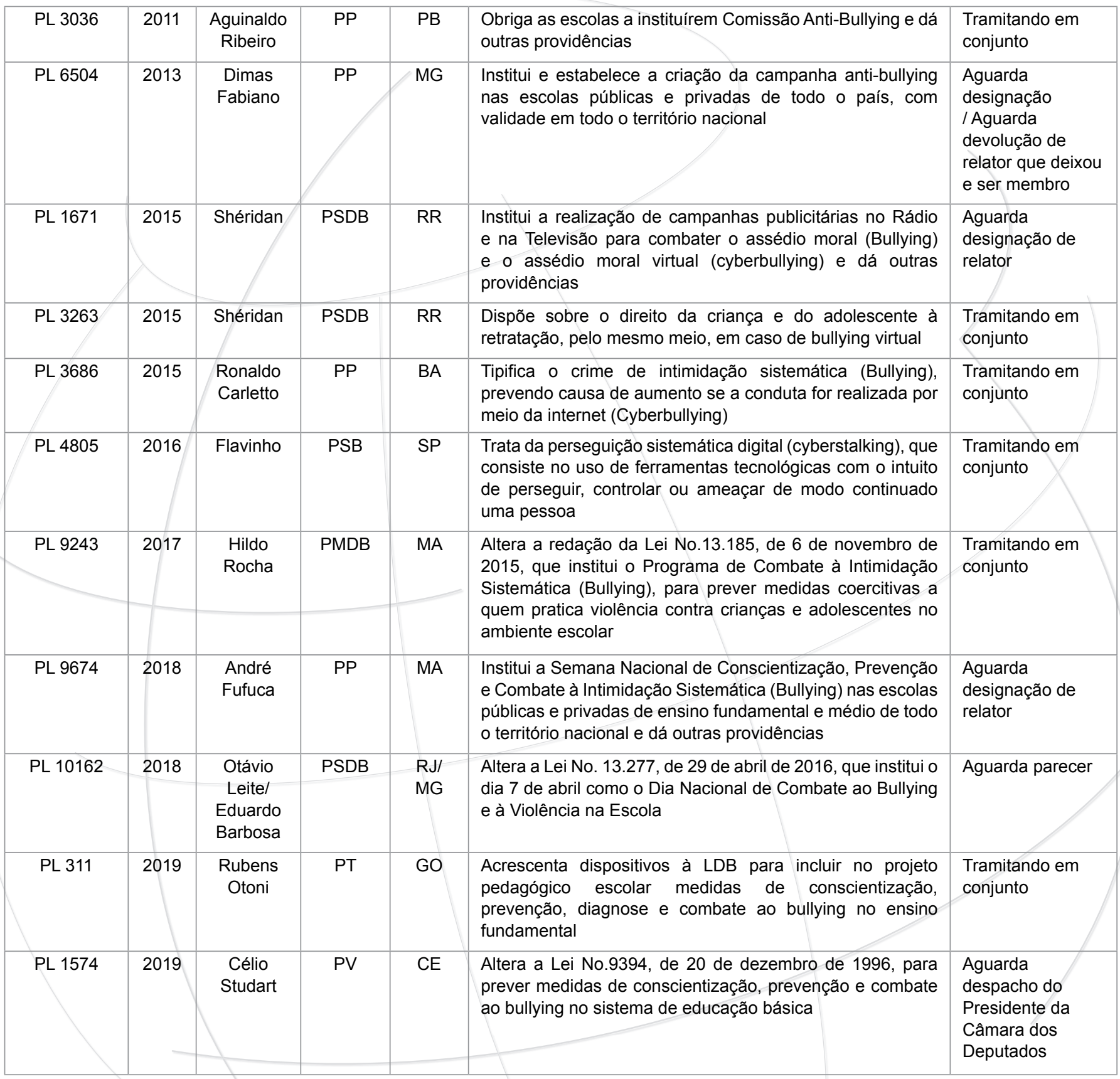


Tabela 2- Proposições Legislativas - palavra-chave "violência escolar"7

\begin{tabular}{|c|c|c|c|c|c|c|}
\hline No. Proposição & Ano & Autor & Partido & Estado & Ementa & Situação \\
\hline PL 2057 & 1991 & $\begin{array}{l}\text { Aloizio Mercadante/ } \\
\text { Fábio Feldmann/ } \\
\text { José Saboia/ } \\
\text { Nelson Jobim/ } \\
\text { Sidney de Miguel }\end{array}$ & $\begin{array}{l}\mathrm{PT} / \\
\mathrm{PSDB} / \\
\mathrm{PSB} / \\
\mathrm{PMDB} / \\
\mathrm{PDT}\end{array}$ & $\begin{array}{l}\text { SPI } \\
\text { SPI } \\
\text { MA/ } \\
\text { RS/ } \\
\text { RJ }\end{array}$ & Dispõe sobre o Estatuto das Sociedades Indígenas & $\begin{array}{l}\text { Pronta para } \\
\text { pauta no } \\
\text { Plenário }\end{array}$ \\
\hline PL 5689 & 2009 & Acélio Casagrande & PMDB & SC & $\begin{array}{l}\text { Institui o "Programa Educacional de Resistência às } \\
\text { Drogas e à Violência - PROERD" nas escolas das } \\
\text { redes pública e privada }\end{array}$ & $\begin{array}{l}\text { Tramitando } \\
\text { em } \\
\text { conjunto }\end{array}$ \\
\hline PL 6928 & 2010 & Luiz Bassuma & PV & BA & $\begin{array}{l}\text { Altera o art. } 27 \text { da Lei No. } 9394 \text {, de } 20 \text { de dezembro } \\
\text { de } 1996 \text {, para inserir, entre as diretrizes curriculares } \\
\text { da educação básica, a promoção da cultura de paz }\end{array}$ & $\begin{array}{l}\text { Tramitando } \\
\text { em } \\
\text { conjunto }\end{array}$ \\
\hline PL 350 & 2011 & Marcelo Aguiar & PSC & SP & Cria o Programa de Combate ao Bullying Escolar & $\begin{array}{l}\text { Tramitando } \\
\text { em } \\
\text { conjunto }\end{array}$ \\
\hline PL 1494 & 2011 & Junji Abe & DEM & SP & Dispõe sobre o crime de intimidação vexatória & $\begin{array}{l}\text { Tramitando } \\
\text { em } \\
\text { conjunto }\end{array}$ \\
\hline PL 6010 & 2013 & $\begin{array}{l}\text { Comissão } \\
\text { Parlamentar } \\
\text { Mista de Inquérito } \\
\text { com a finalidade } \\
\text { de investigar } \\
\text { a situação da } \\
\text { violência contra a } \\
\text { mulher }\end{array}$ & & & $\begin{array}{l}\text { Altera o art. } 27 \text { da Lei No. } 9394 \text {, de } 20 \text { de dezembro } \\
\text { de } 1996, \text { que estabelece as diretrizes e bases da } \\
\text { educação nacional, para explicitar a necessidade } \\
\text { dos conteúdos curriculares da educação básica } \\
\text { enfatizarem como diretriz o respeito à igualdade de } \\
\text { gênero e na prevenção e enfrentamento à violência } \\
\text { doméstica e contra as pessoas em situação de } \\
\text { vulnerabilidade }\end{array}$ & $\begin{array}{l}\text { Pronta para } \\
\text { pauta no } \\
\text { Plenário }\end{array}$ \\
\hline PL 3795 & 2015 & Ezequiel Teixeira & PMB & RJ & $\begin{array}{l}\text { Altera a redação dos artigos } 32 \text { e } 36 \text { da Lei No. } \\
9394 \text {, de } 20 \text { de dezembro de } 1996 \text { (Lei de Diretrizes } \\
\text { e Bases da Educação Nacional), para inserir novas } \\
\text { disciplinas obrigatórias nos currículos dos ensinos } \\
\text { fundamental e médio }\end{array}$ & $\begin{array}{l}\text { Tramitando } \\
\text { em } \\
\text { conjunto }\end{array}$ \\
\hline PL 4507 & 2016 & Rômulo Gouveia & PSD & PB & $\begin{array}{l}\text { Proíbe a comercialização, a exposição e a distribuição } \\
\text { de material escolar que contenha imagem que } \\
\text { estimule a violência ou a exploração sexual. }\end{array}$ & $\begin{array}{l}\text { Apensado } \\
\text { ao PL } \\
3010 / 2011\end{array}$ \\
\hline PL 4620 & 2016 & $\begin{array}{l}\text { Carlos Henrique } \\
\text { Gaguim }\end{array}$ & PMB & TO & $\begin{array}{l}\text { Acrescenta parágrafo ao art. } 23 \text { da Lei No.11.340, } \\
\text { de } 7 \text { de agosto de 2006, para assegurar aos } \\
\text { dependentes em idade escolar de mulher vítima de } \\
\text { violência doméstica ou familiar, em caso de mudança } \\
\text { de domicílio por ordem judicial, o direito à matrícula } \\
\text { em escolas de educação básica mais próximas da } \\
\text { nova residência }\end{array}$ & $\begin{array}{l}\text { Tramitando } \\
\text { em } \\
\text { conjunto }\end{array}$ \\
\hline PL 8599 & 2017 & Geovânia de Sá & PSDB & SC & $\begin{array}{l}\text { Acrescenta dispositivo à Lei No. } 11.340 \text {, de } 7 \text { de } \\
\text { agosto de 2006, para dispor sobre a prioridade da } \\
\text { mulher que sofre violência doméstica à vaga para } \\
\text { seus filhos nos centros de educação infantil. NOVA } \\
\text { EMENTA: Altera a Lei No. 11.340, de } 7 \text { de agosto de } \\
2006 \text { (Lei Maria da Penha), para garantir a matrícula } \\
\text { dos dependentes da mulher vítima de violência } \\
\text { doméstica e familiar em instituição de educação } \\
\text { básica mais próxima de seu domicílio }\end{array}$ & $\begin{array}{l}\text { Aguarda } \\
\text { apreciação } \\
\text { pelo } \\
\text { Senado } \\
\text { Federal }\end{array}$ \\
\hline
\end{tabular}

7 Em 22 de março de 2019 foi realizada nova e última busca no portal da Câmara dos Deputados seguindo a metodologia apresentada. 


\begin{tabular}{|c|c|l|l|l|l|l|}
\hline PL 9243 & 2017 & Hildo Rocha & PMDB & MA & $\begin{array}{l}\text { Altera a redação da Lei No.13.185, de 6 de novembro } \\
\text { de 2015, que institui o Programa de Combate à } \\
\text { Intimidação Sistemática (Bullying), para prever } \\
\text { medidas coercitivas a quem pratica violência contra } \\
\text { crianças e adolescentes no ambiente escolar }\end{array}$ & $\begin{array}{l}\text { Trando } \\
\text { conjunto }\end{array}$ \\
\hline PL 10162 & 2018 & $\begin{array}{l}\text { Otávio Leite/ } \\
\text { Eduardo Barbosa }\end{array}$ & PSDB & $\begin{array}{l}\text { RJ/ } \\
\text { MG }\end{array}$ & $\begin{array}{l}\text { Altera a Lei No. 13.277, de 29 de abril de 2016, } \\
\text { que institui o dia 7 de abril como o Dia Nacional de } \\
\text { Combate ao Bullying e à Violência na Escola }\end{array}$ & $\begin{array}{l}\text { Aguarda } \\
\text { parecer }\end{array}$ \\
\hline PL 852 & 2019 & Sâmia Bomfim & PSOL & SP & $\begin{array}{l}\text { Institui a "Campanha Nacional Maria da Penha nas } \\
\text { Escolas" e dá outras providências. }\end{array}$ & $\begin{array}{l}\text { Aguarda } \\
\text { Designação } \\
\text { de Relator } \\
\text { na } \\
\text { Comissão } \\
\text { de Defesa } \\
\text { dos Direitos } \\
\text { da Mulher }\end{array}$ \\
\hline
\end{tabular}

Vale mencionar que, para a análise do conjunto das proposições, foi necessário verificar também se os PLs acima apresentados estavam apensados a outras propostas, isto é, se a matéria foi anexada para tramitar em conjunto com outra proposição de similar ou idêntica temática. A ideia de se apensar PLs é facilitar a avaliação da Comissão na qual ele se encontra, otimizando tempo e recursos, englobando sugestões num mesmo projeto com o objetivo final de contemplar uma nova lei que atenda às necessidades de todas e todos os legisladores, bem como assistir às demandas da sociedade brasileira.

Nessa pesquisa, observou-se que 18 proposições estão apensadas a outros projetos de lei que não necessariamente foram encontrados pelas palavraschave escolhidas na base de dados da Câmara dos Deputados. É o caso de seis PLs que se encontram apensados ao PL 7457/2010, que não foi indexado pela casa legislativa com as palavras-chave de nossa pesquisa e que, por sua vez, encontra-se anexado ao PL 1785/2011 (incluído na Tabela 1), proposição que engloba um total de nove PLs para serem avaliados em conjunto (Tabela 3). Isso significa que, para além das 25 matérias foco de análise, outras três PL 5612/2009, PL 7157/2010 e PL 7457/2010 - fazem parte da rede de apensos e do corpo de análise desse conjunto de proposições, totalizando desse modo 28 PLs e que estão diretamente envolvidas na temática do bullying nessa casa legislativa.
Tabela 3 - Apensos às Proposições

\begin{tabular}{|c|c|c|c|}
\hline Proposição & Anexada & Anexadas & PL Englobante \\
\hline PL 6928/2010 & & PL 5612/2009 & PL 7157/2010 \\
\hline PL 283/2011 & & PL 7457/2010 & PL 1785/2011 \\
\hline PL 350/ 2011 & PL 283/2011 & & PL 1785/2011 \\
\hline PL 1226/2011 & & PL 7457/2010 & PL 1785/2011 \\
\hline PL 1765/2011 & & PL 7457/2010 & PL 1785/2011 \\
\hline PL 2048/2011 & & PL 7457/2010 & PL 1785/2011 \\
\hline PL 3036/2011 & & PL 7457/2010 & PL 1785/2011 \\
\hline PL 908/2011 & & & PL 1785/2011 \\
\hline PL 1633/2011 & & & PL 1785/2011 \\
\hline PL 1841/2011 & PL 283/2011 & PL 7457/2010 & PL 1785/2011 \\
\hline PL 1494/2011 & & & PL 1011/2011 \\
\hline PL 1573/2011 & & & PL 1011/2011 \\
\hline PL 1671/2015 & & PL 1573/2011 & PL 1011/2011 \\
\hline PL 3263/2015 & & PL 1573/2011 & PL 1011/2011 \\
\hline PL 3686/2015 & & PL 1573/2011 & PL 1011/2011 \\
\hline PL 4805/2016 & & PL 1573/2011 & PL 1011/2011 \\
\hline PL 9243/2017 & PL 4805/2016 & PL 1573/2011 & PL 1011/2011 \\
\hline PL 311/2019 & & & PL 9674/2018 \\
\hline
\end{tabular}

Com a leitura da ementa e do inteiro teor das 28 proposições, notou-se que algumas propostas possuem textos e objetivo semelhantes. A fim de facilitar a compreensão do que esse conjunto representa, foram criadas seis categorias analíticas de acordo com os propósitos a que se destina a criação de uma nova lei. São elas: formação; informatização; mudanças na LDB; penalização; responsabilização; e, sensibilização. Vale mencionar que alguns PLs contam com propósitos em mais de duas categorias e outros com apenas um foco específico, conforme tabela 4 a seguir. 
Tabela 4 - Lista de Projetos de Lei e respectivas categorias

\begin{tabular}{|c|c|c|c|c|c|c|c|c|c|}
\hline $\begin{array}{l}\text { No. } \\
\text { Proposição }\end{array}$ & Ano & Autor & Partido & Estado & Ementa & Categorias & & & \\
\hline PL 7157 & 2010 & Paulo Paim & PT & RS & $\begin{array}{l}\text { Altera os arts. } 3^{\circ}, 14 \text { e } 67 \text { e } \\
\text { acresce o art. } 67-A \text { à Lei } n^{\circ} \\
9.394, \text { de } 20 \text { de dezembro } \\
\text { de } 1996 \text {, que estabelece as } \\
\text { diretrizes e bases da edu- } \\
\text { cação nacional (LDB), para } \\
\text { fortalecer a cultura da paz } \\
\text { nas escolas e nas comuni- } \\
\text { dades adjacentes. }\end{array}$ & $\begin{array}{l}\text { Mudança } \\
\text { na LDB }\end{array}$ & $\begin{array}{l}\text { Sensibi- } \\
\text { lização }\end{array}$ & & \\
\hline PL 7457 & 2010 & $\begin{array}{l}\text { Sueli } \\
\text { Vidigal }\end{array}$ & PDT & ES & $\begin{array}{l}\text { Dispõe sobre o desenvolvi- } \\
\text { mento de política "antibully- } \\
\text { ing" por instituições de en- } \\
\text { sino e de educação infantil, } \\
\text { públicas ou privadas, com } \\
\text { ou sem fins lucrativos. }\end{array}$ & Formação & $\begin{array}{l}\text { Sensibi- } \\
\text { lização }\end{array}$ & $\begin{array}{l}\text { Responsa- } \\
\text { bilização }\end{array}$ & $\begin{array}{l}\text { Informa- } \\
\text { tização }\end{array}$ \\
\hline PL 283 & 2011 & $\begin{array}{l}\text { Thiago } \\
\text { Peixoto }\end{array}$ & PMDB & GO & $\begin{array}{l}\text { Dispõe sobre a inclusão } \\
\text { de medidas de con- } \\
\text { scientização, prevenção, } \\
\text { diagnose e combate ao bul- } \\
\text { lying escolar no projeto ped- } \\
\text { agógico elaborado pelas } \\
\text { escolas públicas e privadas } \\
\text { em todo o território nacion- } \\
\text { al, e dá outras providências }\end{array}$ & $\begin{array}{l}\text { Sensibi- } \\
\text { lização }\end{array}$ & Formação & $\begin{array}{l}\text { Informa- } \\
\text { tização }\end{array}$ & \\
\hline PL 1011 & 2011 & Fábio Faria & PMN & RN & $\begin{array}{l}\text { Define o crime de intimi- } \\
\text { dação escolar no Código } \\
\text { Penal Brasileiro e dá outras } \\
\text { providências }\end{array}$ & $\begin{array}{l}\text { Penal- } \\
\text { ização }\end{array}$ & & & \\
\hline PL 1226 & 2011 & $\begin{array}{l}\text { Sandro } \\
\text { Mabel }\end{array}$ & PR & GO & $\begin{array}{l}\text { Insere o art.9o- A e acres- } \\
\text { centa os incisos IX e X ao } \\
\text { art. } 12 \text { da Lei } 9394 \text {, de } 20 \\
\text { de dezembro de } 1996, \text { para } \\
\text { determinar a criação de } \\
\text { medidas de prevenção e } \\
\text { combate a práticas de in- } \\
\text { timidação sistemática nas } \\
\text { escolas de educação básica }\end{array}$ & $\begin{array}{l}\text { Mudança } \\
\text { na LDB }\end{array}$ & $\begin{array}{l}\text { Sensibi- } \\
\text { lização }\end{array}$ & $\begin{array}{l}\text { Responsa- } \\
\text { bilização }\end{array}$ & \\
\hline PL 1494 & 2011 & Junji Abe & DEM & SP & $\begin{array}{l}\text { Dispõe sobre o crime de in- } \\
\text { timidação vexatória }\end{array}$ & $\begin{array}{l}\text { Penal- } \\
\text { ização }\end{array}$ & & & \\
\hline
\end{tabular}




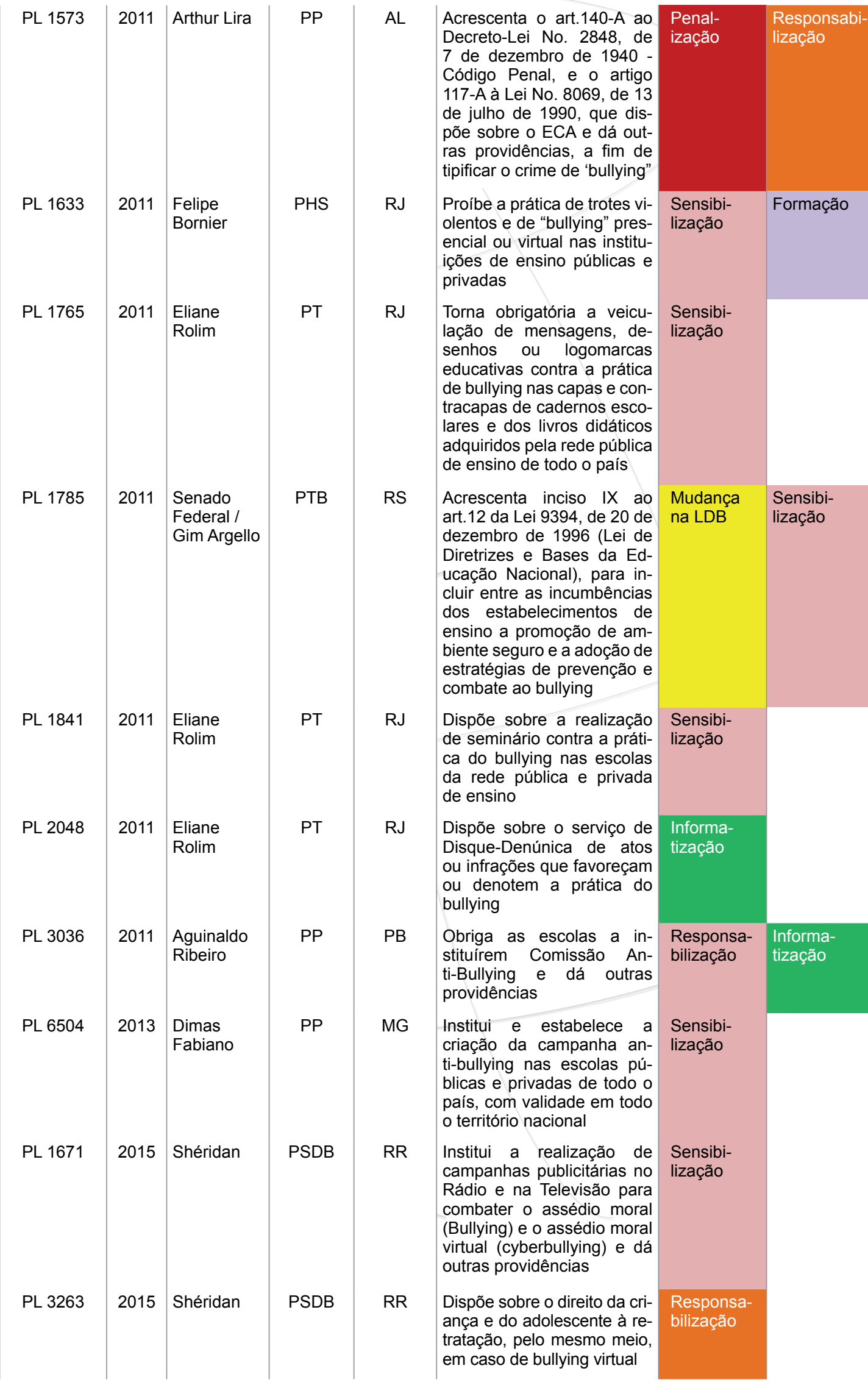

Acrescenta o art.140-A ao 7 de dezembro de 1940 e o artigo (utho 13 ras providências, a fim de lação de mensagens, deart.12 da Lei 9394, de 20 de dezembro de 1996 (Lei de tabelecimentos de Dispõe sobre a realização da rede pública e privada

Disque-Denúnica de atos infrações que favoreçam u denotem a prática do ti-Bullying e dá outras providências

criação da campanha an-

Sensibi-

ti-bullying nas escolas públicas e privadas de todo o com validade em todo combater o assédio moral Bullying) e o assédio mora irtual (cyberbullying) e dá

ança e do adolescente à rede bullying virtual

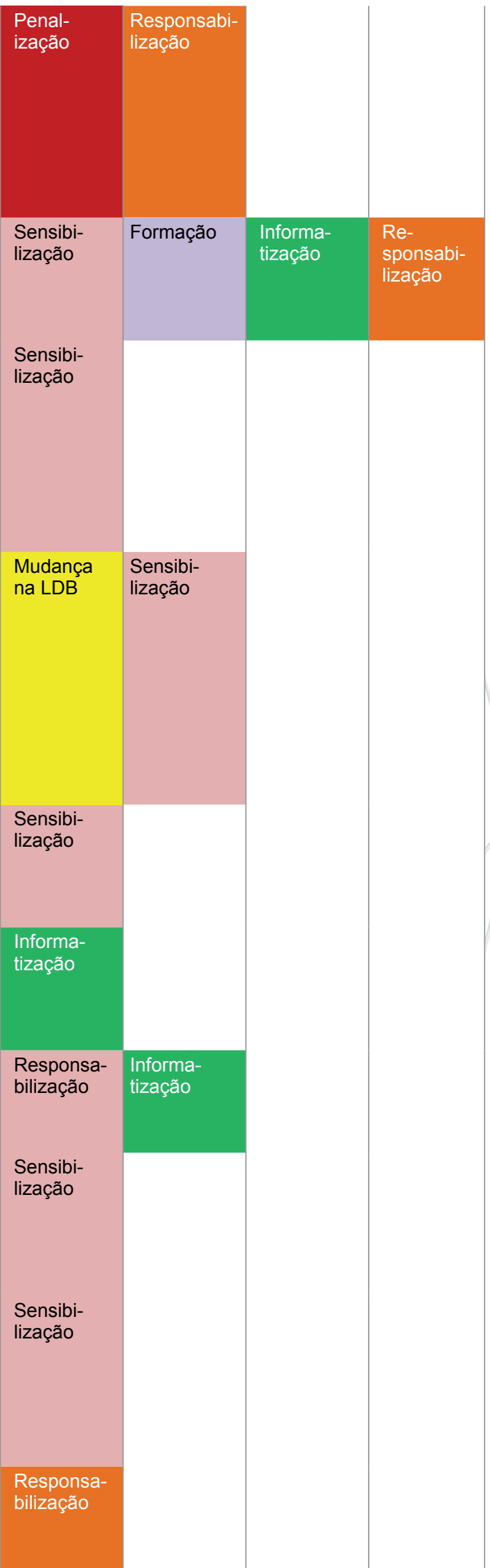




\begin{tabular}{|c|c|c|c|c|c|c|c|c|}
\hline PL 3686 & 2015 & \begin{tabular}{|l|} 
Ronaldo \\
Carletto
\end{tabular} & PP & BA & $\begin{array}{l}\text { Tipifica o crime de intimi- } \\
\text { dação sistemática (Bully- } \\
\text { ing), prevendo causa de } \\
\text { aumento se a conduta for } \\
\text { realizada por meio da inter- } \\
\text { net (Cyberbullying) }\end{array}$ & $\begin{array}{l}\text { Responsa- } \\
\text { bilização }\end{array}$ & & \\
\hline PL 3795 & 2015 & $\begin{array}{l}\text { Ezequiel } \\
\text { Teixeira }\end{array}$ & PMB & RJ & $\begin{array}{l}\text { Altera a redação dos ar- } \\
\text { tigos } 32 \text { e } 36 \text { da Lei No. } \\
9394, \text { de } 20 \text { de dezembro } \\
\text { de } 1996 \text { (Lei de Diretrizes } \\
\text { e Bases da Educação Na- } \\
\text { cional), para inserir novas } \\
\text { disciplinas obrigatórias nos } \\
\text { currículos dos ensinos fun- } \\
\text { damental e médio }\end{array}$ & $\begin{array}{l}\text { Mudança } \\
\text { na LDB }\end{array}$ & Formação & \\
\hline PL 4805 & 2016 & Flavinho & PSB & $\mathrm{SP}$ & $\begin{array}{l}\text { Trata da perseguição sis- } \\
\text { temática digital (ciberstalk- } \\
\text { ing), que consiste no uso de } \\
\text { ferramentas tecnológicas } \\
\text { com o intuito de perseguir, } \\
\text { controlar ou ameaçar de } \\
\text { modo continuado uma pes- } \\
\text { soa }\end{array}$ & $\begin{array}{l}\text { Sensibi- } \\
\text { lização }\end{array}$ & $\begin{array}{l}\text { Responsabi- } \\
\text { lização }\end{array}$ & $\begin{array}{l}\text { Informa- } \\
\text { tização }\end{array}$ \\
\hline PL 9243 & 2017 & $\begin{array}{l}\text { Hildo } \\
\text { Rocha }\end{array}$ & PMDB & MA & $\begin{array}{l}\text { Altera a redação da Lei } \\
\text { No.13.185, de } 6 \text { de novem- } \\
\text { bro de } 2015 \text {, que institui o } \\
\text { Programa de Combate à In- } \\
\text { timidação Sistemática (Bul- } \\
\text { lying), para prever medidas } \\
\text { coercitivas a quem pratica } \\
\text { violência contra crianças e } \\
\text { adolescentes no ambiente } \\
\text { escolar }\end{array}$ & $\begin{array}{l}\text { Sensibi- } \\
\text { lização }\end{array}$ & & \\
\hline PL 9674 & 2018 & $\begin{array}{l}\text { André } \\
\text { Fufuca }\end{array}$ & PP & MA & $\begin{array}{l}\text { Institui a Semana Nacion- } \\
\text { al de Conscientização, } \\
\text { Prevenção e Combate à } \\
\text { Intimidação Sistemática } \\
\text { (Bullying) nas escolas pú- } \\
\text { blicas eprivadas de ensino } \\
\text { fundamental e médio de to- } \\
\text { doo território nacional e dá } \\
\text { outras providências }\end{array}$ & $\begin{array}{l}\text { Sensibi- } \\
\text { lização }\end{array}$ & & \\
\hline PL 10162 & 2018 & $\begin{array}{l}\text { Otávio } \\
\text { Leite/ } \\
\text { Eduardo } \\
\text { Barbosa }\end{array}$ & PSDB & $\mathrm{RJ} / \mathrm{MG}$ & $\begin{array}{l}\text { Altera a Lei No. 13.277, de } \\
29 \text { de abril de 2016, que in- } \\
\text { stitui o dia } 7 \text { de abril como } \\
\text { o Dia Nacional de Combate } \\
\text { ao Bullying e à Violência na } \\
\text { Escola }\end{array}$ & $\begin{array}{l}\text { Sensibi- } \\
\text { lização }\end{array}$ & & \\
\hline PL 311 & 2019 & $\begin{array}{l}\text { Rubens } \\
\text { Otoni }\end{array}$ & PT & GO & $\begin{array}{l}\text { Acrescenta dispositivos à } \\
\text { LDB para incluir no projeto } \\
\text { pedagógico escolar medi- } \\
\text { das de conscientização, } \\
\text { prevenção, diagnose e } \\
\text { combate ao bullying no en- } \\
\text { sino fundamental }\end{array}$ & $\begin{array}{l}\text { Mudança } \\
\text { na LDB }\end{array}$ & $\begin{array}{l}\text { Sensibi- } \\
\text { lização }\end{array}$ & Formação \\
\hline PL 1574 & 2019 & $\begin{array}{l}\text { Célio } \\
\text { Studart }\end{array}$ & PV & $\mathrm{CE}$ & $\begin{array}{l}\text { Altera a Lei No.9394, de } 20 \\
\text { de dezembro de 1996, para } \\
\text { prever medidas de con- } \\
\text { scientização, prevenção e } \\
\text { combate ao bullying no sis- } \\
\text { tema de educação básica }\end{array}$ & $\begin{array}{l}\text { Mudança } \\
\text { na LDB }\end{array}$ & $\begin{array}{l}\text { Sensibi- } \\
\text { lização }\end{array}$ & \\
\hline
\end{tabular}




\section{Resultados e análise}

A partir do apresentado na metodologia e na Tabela 4, é possível constatar que as e os parlamentares da Câmara dos Deputados possuem focos bastante específicos na propositura de Projetos de Lei: alterar a LDB para inclusão de disciplinas; capacitar professores das escolas públicas e privadas; sensibilizar, principalmente, estudantes, pais e comunidade escolar, além da opinião pública; informatizar órgão de denúncia, bem como registrar as ocorrências de bullying no espaço escolar; e, por fim, tipificar o bullying como crime, penalizando e/ou responsabilizando o/ a autor(a) da agressão.

Dentre os 28 PLs, observa-se que 13 propostas foram apresentadas por parlamentares da Região Sudeste, e cinco delas são oriundas do Estado de São Paulo, cinco do Rio de Janeiro, um feito em parceria entre parlamentares de Minas Gerais e Rio de Janeiro, um do Espírito Santo e um, exclusivamente por parlamentar mineiro. A Região Nordeste apresentou oito PLs, sendo dois do Estado da Bahia, dois do Maranhão, tendo Alagoas, Ceará, Paraíba e Rio Grande do Norte apresentado uma proposta cada um. Goiás, Roraima e Rio Grande do Sul foram os outros Estados que representaram suas regiões, sendo responsáveis pela apresentação de sete PLs ao total. Ainda que Estados como Paraná, Mato Grosso e Mato Grosso do Sul sejam alguns em que mais estudantes revelaram que o bullying é uma prática comum nas escolas, como informado nas edições da PeNSE, a não apresentação de PLs desses e de outros Estados pode oferecer indícios para alguns questionamentos como: Quais os focos de interesse dos e das parlamentares nesses Estados para o combate e prevenção do bullying? Há políticas estaduais que já estão sendo implementadas nessas áreas e, consequentemente, não haveria a necessidade de novas proposições em âmbito federal? Estão sendo realizadas campanhas informativas nesses Estados e, portanto, parlamentares estão focando suas atuações em outros temas de combate à violência de modo geral? Tais questionamentos não serão respondidos neste artigo, visto que o foco é tratar do conjunto de proposições apresentadas no âmbito federal e não analisar especificidades dos Estados aos quais não estiveram representados nas proposituras, porém, seguem os questionamentos para investigações futuras para pesquisadores do tema.

Vale salientar, no entanto, que até o ano de 2011, apenas quatro proposições haviam sido apresentadas na Câmara dos Deputados, em Brasília, e até a data do episódio de Realengo, um total de seis. A partir de 07 de abril de 2011, somente naquele ano, foram apresentadas outras 10 propostas, sendo que a primeira, PL 1011/2011, de autoria do deputado federal Fábio Faria (PMN/RN), foi posta no sistema de tramitação cinco dias após o ocorrido.

De modo geral, quando ocorre um evento em que a opinião pública é sensibilizada ou quando são feitas pesquisas junto à população sobre um determinado tema e isso é noticiado amplamente pela grande mídia, parlamentares procuram dar resposta à sociedade por meio da criação de proposições legislativas. Aliado a esses dois fatores, a composição da Câmara também influencia que tipos de PLs serão apresentados. $\mathrm{Na}$ última legislatura, por exemplo, o fato do Congresso contar com a bancada mais conservadora desde 1964 (MARTINS, 2014), possibilitou que pautas como a redução da idade penal voltassem à tona no Plenário, bem como um número acentuado de novas proposições sobre esse tema viessem a tramitar na Câmara e também no Senado.

Além disso, do número total de matérias em tramitação até o presente momento, apenas sete foram apresentadas por somente quatro deputadas federais. No aspecto 'gênero', devemos recordar que no período da 54a. Legislatura (2010-2014), apenas 45 deputadas federais ocupavam a Câmara dos Deputados, enquanto que na atual (2019-2023), houve um aumento desse número, passando para 77 representantes, o que equivale a $15 \%$ das 513 cadeiras (CÂMARA DOS DEPUTADOS, 2018). O baixo número de muIheres ocupando cargos do Legislativo Federal apenas demonstra a imensa desigualdade de gênero na sociedade brasileira como um todo, não significando, outrossim, que o bullying não esteja presente nas preocupações das parlamentares. $O$ fato apenas reverbera a desigualdade de gênero da sociedade na Câmara dos Deputados, inclusive, vide que a Câmara usa a flexão masculina para denominação da casa legislativa ${ }^{8}$.

8 Talvez se possa pensar, a partir de reflexão sobre o uso dos pronomes masculinos, uma mudança no nome da casa legislativa para Câmara de Parlamentares, Câmara de Congressistas ou 
No que se refere aos partidos ${ }^{9}$ envolvidos nesse tema, à época da apresentação da proposição legislativa ${ }^{10}$, destacam-se o Partido Progressita (PP) e o Partido dos Trabalhadores (PT), com cinco proposições apresentadas, respectivamente, seguidos do Partido da Social Democracia Brasileira (PSDB) e do Partido Verde (PV), com três matérias cada um. O Partido do Movimento Democrático Brasileiro (PMDB), atual MDB, e o Partido da República (PR) contam com dois PLs em tramitação, respectivamente. Partidos como DEM (Democratas), PDT (Partido Democrático Trabalhista), PHS (Partido Humanista da Solidariedade), PMB (Partido da Mulher Brasileira), PMN (Partido da Mobilização Nacional), PSC (Partido Social Cristão), PSB (Partido Socialista Brasileiro) e PTB (Partido Trabalhista Brasileiro) apresentaram apenas um cada.

Devemos recordar que o Brasil é o país com o maior número de partidos efetivos em todo o mundo (SCHEREIBER, 2016), contando atualmente com 35 siglas, sendo que o PT possui 54 das atuais 513 cadeiras da instituição e o bloco de apoio ao governo composto por PSL (52), PP (38), PSD (35), MDB (34), PR (33), PRB (30), DEM (29), PSDB (29), PTB (10), PSC (8) e PMN (3) tem 301 deputados (CRISTALDO, 2019). Assim, o bloco com maior número de representantes na Câmara dos Deputados conta com mais de $46 \%$ das proposições legislativas sobre bullying.

O aspecto da sensibilização foi apresentado pela maioria das proposições e 18 PLs contam com essa perspectiva, ainda que algumas propostas ampliem o escopo para a formação e a informatização e, outros, mirem na cultura de paz e mudanças na LDB para atingir a sensibilização. Desse modo, é possível verificar uma preocupação na disseminação de informações sobre bullying nas escolas, bem como à sociedade de modo geral por meio de campanhas, como é possível observar em alguns artigos e incisos de alCâmara de Deputadas e Deputados.

9 Buscou-se inserir os nomes dos partidos com maior número de PLs apresentados, por extenso, a fim de rememorar o que significam as siglas desses partidos no atual contexto político brasileiro, visto que, como diria Bakhtin (2010, p. 47) "Classe social e comunidade semiótica não se confundem. Pelo segundo termo entendemos a comunidade que utiliza um único e mesmo código ideológico de comunicação. Assim, classes sociais diferentes servem-se de uma só e mesma língua. Consequentemente, em todo signo ideológico confrontam-se índices de valor contraditórios. O signo se torna a arena onde se desenvolve a luta de classes".

10 Vale observar que parlamentares mudam de partido no decorrer da legislatura ou quando há nova eleição. gumas proposições:

"Art. $1^{\circ}$ As instituições de ensino públicas ou privadas, com ou sem fins lucrativos, no País ficam condicionadas à política "antibullying", nos termos desta Lei. (...)

Art. $3^{\circ}$ No âmbito de cada instituição a que se refere esta Lei, a política "antibullying" tem como objetivos: I - reduzir a prática de violência dentro e fora das instituições de que trata esta Lei e melhorar o desempenho escolar; II - promover a cidadania, a capacidade empática e o respeito aos demais; III - disseminar conhecimento sobre o fenômeno "bullying" nos meio de comunicação e nas instituições de que trata esta Lei, entre os responsáveis legais pelas crianças e adolescentes nela matriculados" (IZAR, 2011).

"O Congresso Nacional decreta: Art. $1^{\circ}$ Fica a união obrigada a veicular mensagens, desenhos ou logomarcas educativas contra a prática do bullying, nas capas e contracapas dos cadernos escolares e dos livros didáticos adquiridos pela rede pública de ensino de todo o país" (ROLIM, 2011).

"Art. $1^{\circ}$ - Ficam as escolas da rede pública e privada de ensino obrigadas a realizarem, no primeiro semestre de cada ano letivo, seminário contra a prática do bullying com duração de no mínimo quatro horas. Parágrafo único - O seminário de que trata o caput deste artigo será destinado aos alunos, professores, diretores e demais funcionários da unidade escolar, podendo ser convidados a critério da diretoria da escola, os pais ou responsáveis dos referidos alunos e integrantes da comunidade local.

Art. $2^{\circ}$ - Para viabilizar a realização do seminário de que trata o caput, a escola poderá convidar profissionais habilitados de outras instituições, caso não tenha nenhum professor capacitado na escola. Art. $3^{\circ}$ - Visando uma melhor compreensão dos alunos da educação infantil, o seminário poderá ser realizado de forma lúdica, apresentado mediante musicais ou peças teatrais, com duração reduzida para duas horas, no mínimo" (ROLIM, 2011a). 
"Art. $4^{\circ}$ Objetivando a aplicação desta lei, as instituições de ensino estabelecerão programas visando a:

I - organizar atividades, eventos ou gestos de solidariedade para com pessoas físicas e entidades assistenciais ou filantrópicas;

(...)

$\mathrm{V}$ - incluir, no projeto político-pedagógico da instituição de ensino, após ampla discussão, medidas de conscientização, prevenção e combate ao bullying;

VII - desenvolver campanhas educativas, informativas e de conscientização, inclusive esclarecendo sobre os aspectos éticos e legais que envolvem o bullying (...)" (BORNIER, 2011).

"O CONGRESSO NACIONAL DECRETA: Artigo $1^{\circ}$ - A campanha anti-bullying deverá ser estabelecida no período de uma semana durante o ano letivo no primeiro bimestre escolar em todas as instituições de ensino fundamental e médio de todos os estados brasileiros. Artigo $2^{\circ}$ - A campanha tem por objetivo prevenir e combater a prática de bullying nas escolas; esclarecer aspectos legais e éticos que envolvem o bullying; desenvolver através das atividades educacionais e informativas a conscientização de suas causas e consequências" (FABIANO, 2013).

"Art. $1^{\circ} \mathrm{O}$ Governo Federal realizará campanhas publicitárias no Rádio e na Televisão com o objetivo de combater o assédio moral (bullying) e o assédio moral virtual (cyberbullying).

Art. $2^{\circ}$ As inserções publicitárias radiofônicas e televisivas deverão ser feitas em horários de maior pico de audiência para atingir o maior número de pessoas possível. Art. $3^{\circ}$ As inserções deverão durar, no mínimo, dois meses. Art. $4^{\circ}$ Esta Lei entra em vigor na data da sua publicação" (SHÉRIDAN, 2015).

"Art. $1^{\circ}$ - O artigo $1^{\circ}$ da Lei $n^{\circ} 13.277$, de 29 de abril de 2016, que institui o dia 7 de abril como o Dia Nacional de Combate ao Bullying e à Violência na Escola, passa a vigorar com a seguinte redação: "Art. $1^{\circ}$ - É instituído o Dia Nacional de
Combate ao Bullying e a Violência Escolar - Anjos de Realengo, a ser celebrado anualmente no dia 07 de abril." (LEITE E BARBOSA, 2018).

Por meio dos excertos acima, observa-se uma preocupação das e dos parlamentares em sensibilizar a opinião pública para fins de mobilização, prevenção e combate ao bullying. Nesse aspecto, a atual legislação concernente já prevê tais iniciativas pela institucionalização do Dia Nacional de Combate ao Bullying e à Violência na Escola, por meio da Lei No. 13.277, de 29 de abril de 2016 e pela LDB (BRASIL, 1996) e respectiva inclusão dos incisos IX e $X$, em que há um direcionamento para "IX - promover medidas de conscientização, de prevenção e de combate a todos os tipos de violência, especialmente a intimidação sistemática (bullying), no âmbito das escolas ${ }^{11}$; e também para " $X$ - estabelecer ações destinadas a promover a cultura de paz nas escolas"12.

Além disso, a Lei No. 13.185, de 6 de novembro de 2015, que institui o Programa de Combate à Intimidação Sistemática, já prevê a implementação de campanhas de educação, conscientização e informação, bem como a integração dos meios de comunicação de massa nesse trabalho, somado à promoção de medidas de conscientização e prevenção em ambiente escolar, clubes e agremiações recreativas, como explicitado no Art. $4^{\circ}$, incisos II, VI, IX e Art. $5^{\circ}$ da referida lei. Ou seja, as propostas acima não trazem um conteúdo novo para o que já foi legislado, ainda que se possa inserir um novo aposto ou vocativo como justificado no PL 10162/ 2018 dos deputados Otávio Leite e Eduardo Barbosa.

Também é preciso salientar que a norma jurídica foi sancionada em 2015 e, em uma busca nos portais governamentais do Ministério da Educação e Ministério da Justiça (MJ), não há uma campanha nacional direcionada ao combate do bullying. Contudo, em 6 de abril de 2018, véspera da data nacional criada pela Lei No.13.663 de 2018, o MEC noticiou seu apoio ao enfrentamento ao bullying e violência nas escolas, criando o Pacto Universitário pela Promoção do Respeito à

11 Inciso incluso pela Lei No. 13.663 , de 14 de maio de 2018 , que "Altera o art. 12 da Lei $n^{\circ}$ 9.394, de 20 de dezembro de 1996, para incluir a promoção de medidas de conscientização, de prevenção e de combate a todos os tipos de violência e a promoção da cultura de paz entre as incumbências dos estabelecimentos de ensino" (Brasil, 2018).

12 Idem. 
Diversidade, da Cultura da Paz e dos Direitos Humanos. Tal acordo possibilita que o MEC apoie "projetos de formação continuada para profissionais da educação (docentes e gestores) por meio do Pacto Universitário de Educação em Direitos Humanos" (BRASIL, s/d), iniciativa conjunta desse órgão e do Ministério da Justiça e Cidadania para a promoção da educação em direitos humanos no ensino superior. Ressalte-se que no pacto não há menção sobre repasse de investimentos para o desenvolvimento de campanhas específicas em âmbito escolar. Ou seja, docentes e gestores escolares, para além de suas atividades, precisam contar com uma dose extra de criatividade para cumprir a legislação a respeito do bullying.

Em termos de campanha em âmbito nacional encontra-se apenas a iniciativa realizada pelo Conselho Nacional de Justiça (2010). A instituição lançou uma cartilha escrita pela autora do livro "Bullying: Mentes Perigosas nas Escolas" e, de acordo com a instituição, "ao menos 6.190 cartilhas sobre bullying foram doadas pelo conselho nos últimos três anos" (CNJ, 2018).

Segundo o Censo Escolar da Educação Básica 2018, no Brasil há 181,9 mil escolas de educação e foram registradas 48,5 milhões de matrículas (INEP, 2018). Isso equivale dizer que as mais de seis mil cartiIhas do CNJ, louvável iniciativa da instituição, são uma sutil degustação diante da necessidade de uma refeição completa para a solução desse quesito sensibilização no âmbito das campanhas. As iniciativas de promoção e conscientização, em boa parte dos achados nas mídias digitais, são realizadas por alguns governos estaduais, municipais, ONGs e iniciativas de pessoas físicas, coletivos e/ou movimentos sociais em nível local. Porém, mesmo havendo uma norma jurídica em âmbito federal sobre campanhas de sensibilização, é possível afirmar que há um canyon entre a teoria e a prática a respeito de campanhas sobre o tema, dado que esse tipo de iniciativa nunca foi efetivado.

No tocante à categoria 'formação', sete proposições legislativas trazem aspectos de capacitação e formação às e aos docentes e para estudantes como públicos-alvo e outros sete PLs categorizados om 'mudança na LDB', sendo que algumas propostas estão nesses dois eixos. A seguir, alguns excertos retirados dos PL 5612/2009, PL 1785/2010, PL 1226/2011, PL 1663/2011, PL 3795/2015 e PL 311/2019 apresenta- dos, respectivamente, pela Dep.Luciana Costa (PR/ $\mathrm{SP})$, pelo Dep. Sandro Mabel (PR/GO), Sen. Gim Argello (PTB/RS), pelo Dep. Felipe Bornier (PHS/RJ, pelo Dep. Ezequiel Teixeira (PMB/ RJ) e pelo Dep. Rubens Otoni (PT/GO) que estão no eixo 'formação' e 'mudança na LDB':

"Art. $1^{\circ}$ - Fica incluída no currículo das Escolas de Educação Básica, Profissional e de Ensino Superior, como matéria obrigatória, a disciplina "CULTURA DE PAZ".

$\S 1^{\circ}$ A disciplina "CULTURA DE PAZ" terá como objetivo primordial a construção de uma genuína cultura de aceitação da diversidade, de tolerância com as diferenças, de compreensão, compaixão e de solidariedade entre os seres humanos.

$\S 2^{\circ} \mathrm{O}$ conteúdo programático da disciplina a que se refere o "caput" deste artigo deverá ser organizado de modo a introduzir o estudo gradual e sistemático dos fatores intervenientes no processo de construção da paz, tais como o estudo das emoções e dos sentimentos, dos conflitos e das suas formas de solução.

Art. $2^{\circ}$ - A disciplina "CULTURA DE PAZ" deverá ser ministrada nos vários anos ou séries escolares com o mínimo de 1 (uma) hora aula semanal. $\S 1^{\circ}$ A hora aula a que se refere o "caput" deste artigo poderá ser atribuída, havendo necessidade, mediante a redução da carga horária de outras disciplinas não obrigatórias.

$\S 2^{\circ}$ A capacitação dos professores poderá ser feita, havendo necessidade, nos horários de trabalho pedagógico coletivos, previstos na jornada de trabalho dos professores, semanalmente, reservados para discussão e preparação das aulas" (COSTA, 2009).

"Art. $1^{\circ} \mathrm{O}$ art. 12 da Lei $\mathrm{n}^{\circ}$ 9.394, de 20 de dezembro de 1996 (Lei de Diretrizes e Bases da Educação Nacional), passa a vigorar acrescido do seguinte inciso IX:

"Art. 12.

IX - promover ambiente escolar seguro, adotando estratégias de prevenção e combate a práticas de intimidação e agressão recorrentes entre os integrantes da comunidade escolar, co- 
nhecidas como bullying." (NR) Art. $2^{\circ}$ Esta Lei entra em vigor na data de sua publicação" (ARGELLO, 2010).

"Art. 9-A. A União apoiará técnica e financeiramente os sistemas de ensino na promoção de medidas de prevenção, diagnóstico e combate a práticas de intimidação sistemática cometidas por alunos nas escolas.

Parágrafo único. Práticas de intimidação sistemática são atos de violência verbal, física ou psicológica praticados de forma repetitiva por um aluno ou grupo de alunos em relação a um ou mais alunos, com o objetivo de constranger, intimidar, depreciar, agredir, causar dor, angústia ou humilhação ao outro."

Art. $2^{\circ}$ Acrescentem-se os seguintes incisos IX e $X$ ao artigo 12 da Lei $n^{\circ} 9.394$, de 20 de dezembro de 1996:

"Art. 12

IX - desenvolver medidas de prevenção, diagnóstico e combate a práticas de intimidação sistemática, com envolvimento de alunos, pais e professores, nos termos definidos pelo parágrafo único do art. $9^{\circ}$-A desta Lei.

X- demandar ao Conselho Tutelar do Município e à representação do Ministério Público apoio para a resolução de casos de intimidação sistemática, quando esgotadas as penalidades previstas no regimento interno escolar" (MABEL, 2011)

(...) IV - capacitar docentes e equipe pedagógica para a implementação das ações de discussão, prevenção, orientação, conciliação e solução dos casos de bullying;

$\mathrm{V}$ - incluir, no projeto político-pedagógico da instituição de ensino, após ampla discussão, medidas de conscientização, prevenção e combate ao bullying;

VI - observar, analisar e identificar eventuais praticantes e vítimas de bullying nas instituições de ensino;

VII - desenvolver campanhas educativas, informativas e de conscientização, inclusive esclarecendo sobre os aspectos éticos e legais que envolvem o bullying; (...)" (BORNIER, 2011).
"Art. $1^{\circ}$ Os artigos 32 e 36 da Lei 9.394, de 20 de dezembro de 1996, (Lei de Diretrizes e Bases da Educação Nacional), passam a vigorar com a seguinte redação:

"Art. 32.

$\S 5^{\circ} \mathrm{O}$ currículo do ensino fundamental incluirá, obrigatoriamente, disciplina que busque o desenvolvimento de atividades para conscientização e prevenção contra a violência no âmbito das relações familiares, tendo como diretriz, inclusive, a Lei 11.340 , de 7 de agosto de 2006, além do conteúdo que trate dos direitos das crianças e dos adolescentes, tendo como diretriz a Lei no 8.069, de 13 de julho de 1990, que institui o Estatuto da Criança e do Adolescente, observada a produção e distribuição de material didático adequado. (NR)

"Art. 36.

IV - Serão incluídas a disciplina com conteúdo que trate da conscientização e prevenção contra a violência no âmbito das relações familiares, tendo como diretriz, inclusive, a Lei 11.340, de 7 de agosto de 2006, a Filosofia e a Sociologia como disciplinas obrigatórias em todas as séries do ensino" (TEIXEIRA, 2015).

"Art. I A Lei de Diretrizes e Bases da Educação, no 9.394, de 20 de dezembro 1996, passa a vigorar acrescido do Art. 28-A com a seguinte redação:

Art. 28-A. As escolas públicas e privadas da educação básica em todo o território nacional deverão incluir em seu projeto pedagógico medidas de conscientização, prevenção, diagnose e combate ao "bullying" escolar.

(...)

$\S 3^{\circ}$ Constituem objetivos a serem atingidos: I - Conscientizar a comunidade escolar sobre - conceito de «bullying», sua abrangência e a necessidade de medidas de prevenção, diagnose e combate; II- prevenir, diagnosticar e combater a prática do «bullying» nas escolas; III - capacitar docentes, equipe pedagógica e servidores da escola para a implementação das ações de discussão, prevenção, orientação e solução do problema; IV - orientar os envolvidos 
em situação de "bullying", visando à recuperação da autoestima, do desenvolvimento psicossocial e da convivência harmônica no ambiente escolar e social; $V$ - envolver a família no processo de construção da cultura de paz nas unidades escolares e perante a sociedade.

$\S 4^{\circ}$ As ações a serem desenvolvidas, como palestras, debates, distribuição de cartilhas de orientação aos pais, alunos, professores, servidores, entre outras iniciativas, deverão ser estabelecidas por meio de Regulamento" (OTONI, 2019).

Tomando como referência a LDB (BRASIL, 1996) e suas atualizações legislativas, a lei preconiza em seu Art. 12, inciso VI e X que os estabelecimentos de ensino terão a incumbência de:

“(...) VI - articular-se com as famílias e a comunidade, criando processos de integração da sociedade com a escola; (...) IX - promover medidas de conscientização, de prevenção e de combate a todos os tipos de violência, especialmente a intimidação sistemática (bullying), no âmbito das escolas (Incluído pela Lei $n^{\circ}$ 13.663, de 2018); $X$ - estabelecer ações destinadas a promover a cultura de paz nas escolas. (Incluído pela Lei ${ }^{\circ}$ 13.663, de 2018).

Além disso, nos artigos 61, 62, 62 A e 86, a referida legislação é precisa no que diz respeito à formação docente:

"Art. 61. Consideram-se profissionais da educação escolar básica os que, nela estando em efetivo exercício e tendo sido formados em cursos reconhecidos, são: (Redação dada pela Lei $\mathrm{n}^{\circ} 12.014$, de 2009)

I - professores habilitados em nível médio ou superior para a docência na educação infantil e nos ensinos fundamental e médio;

\section{(...)}

Parágrafo único. A formação dos profissionais da educação, de modo a atender às especificidades do exercício de suas atividades, bem como aos objetivos das diferentes etapas e modalidades da educação básica, terá como fundamentos: (Incluído pela Lei no 12.014 , de 2009)
I - a presença de sólida formação básica, que propicie o conhecimento dos fundamentos científicos e sociais de suas competências de trabalho (Incluído pela Lei no 12.014, de 2009); II - a associação entre teorias e práticas, mediante estágios supervisionados e capacitação em serviço;

(...)

Art. 62. A formação de docentes para atuar na educação básica far-se-á em nível superior, em curso de licenciatura plena, admitida, como formação mínima para o exercício do magistério na educação infantil e nos cinco primeiros anos do ensino fundamental, a oferecida em nível médio, na modalidade normal. (Redação dada pela lei $n^{\circ} 13.415$, de 2017)

$\S 1^{\circ}$ A União, o Distrito Federal, os Estados e os Municípios, em regime de colaboração, deverão promover a formação inicial, a continuada e a capacitação dos profissionais de magistério. (Incluído pela Lei n 12.056, de 2009).

$\S 2^{2}$ A formação continuada e a capacitação dos profissionais de magistério poderão utilizar recursos e tecnologias de educação a distância. (...)

Art. 62-A. A formação dos profissionais a que se refere o inciso III do art. 61 far-se-á por meio de cursos de conteúdo técnico-pedagógico, em nível médio ou superior, incluindo habilitações tecnológicas. (Incluído pela Lei $n^{\circ} 12.796$, de 2013) Parágrafo único. Garantir-se-á formação continuada para os profissionais a que se refere o caput, no local de trabalho ou em instituições de educação básica e superior, incluindo cursos de educação profissional, cursos superiores de graduação plena ou tecnológicos e de pós-graduação. (Incluído pela Lei n 12.796 , de 2013)

Art. 62-B. O acesso de professores das redes públicas de educação básica a cursos superiores de pedagogia e licenciatura será efetivado por meio de processo seletivo diferenciado. (Incluído pela Lei $n^{\circ} 13.478$, de 2017)

$\S 1$ Terão direito de pleitear o acesso previsto no caput deste artigo os professores das redes públicas municipais, estaduais e federal que ingressaram por concurso público, tenham pelo menos três anos de exercício da profissão e não 
sejam portadores de diploma de graduação" (BRASIL, 1996).

Nesse aspecto, ao comparar o que se propõe nas proposições em tramitação e o que já está garantido na LDB, entende-se que a atual legislação em vigor no país já contempla o tema de prevenção ao bullying com o incisos IX e $X$ do Art. 12 e no que se refere à formação de professores e novos conteúdos sobre Direitos Humanos, nos demais artigos e parágrafos acima listados.

Além disso, o Plano Nacional de Educação (PNE 2014-2024), Lei No.13.005, de 25 de junho de 2014 , tem entre suas diretrizes: superar as desigualdades educacionais, com ênfase na promoção da cidadania e na erradicação de todas as formas de discriminação; melhorar a qualidade da educação; valorizar os (as) profissionais da educação e promover princípios do respeito aos direitos humanos, à diversidade e à sustentabilidade socioambiental, entre outras (BRASIL, 2014). Por meio de 20 metas a serem alcançadas em 10 anos, este PNE traz uma série de estratégias que vão ao encontro da formação proposta nos PLs acima das categorias mencionadas. De um total de 253 estratégias contidas no Anexo do PNE, vejamos apenas algumas das dezenas em que a formação docente consta do documento:

"1.8) promover a formação inicial e continuada dos (as) profissionais da educação infantil, garantindo, progressivamente, o atendimento por profissionais com formação superior;

\section{(...)}

3.1) institucionalizar programa nacional de renovação do ensino médio, a fim de incentivar práticas pedagógicas com abordagens interdisciplinares estruturadas pela relação entre teoria e prática, por meio de currículos escolares que organizem, de maneira flexível e diversificada, conteúdos obrigatórios e eletivos articulados em dimensões como ciência, trabalho, linguagens, tecnologia, cultura e esporte, garantindo-se a aquisição de equipamentos e laboratórios, a produção de material didático específico, a formação continuada de professores e a articulação com instituições acadêmicas, esportivas e culturais;

(...)
4.3) implantar, ao longo deste PNE, salas de recursos multifuncionais e fomentar a formação continuada de professores e professoras para o atendimento educacional especializado nas escolas urbanas, do campo, indígenas e de comunidades quilombolas;

\section{(...)}

7.5) formalizar e executar os planos de ações articuladas dando cumprimento às metas de qualidade estabelecidas para a educação básica pública e às estratégias de apoio técnico e financeiro voltadas à melhoria da gestão educacional, à formação de professores e professoras e profissionais de serviços e apoio escolares, à ampliação e ao desenvolvimento de recursos pedagógicos e a melhoria e expansão da infraestrutura física da rede escolar;

(...)

7.23) garantir políticas de combate à violência na escola, inclusive pelo desenvolvimento de ações destinadas à capacitação de educadores para detecção dos sinais de suas causas, como a violência doméstica e sexual, favorecendo a adoção das providências adequadas para promover a construção da cultura de paz e um ambiente escolar dotado de segurança para a comunidade;

(...)

12.11) fomentar estudos e pesquisas que analisem a necessidade de articulação entre formação, currículo, pesquisa e mundo do trabalho, considerando as necessidades econômicas, sociais e culturais do País;

\section{(...)}

15.9) implementar cursos e programas especiais para assegurar formação específica na educação superior, nas respectivas áreas de atuação, aos docentes com formação de nível médio na modalidade normal, não licenciados ou licenciados em área diversa da de atuação docente, em efetivo exercício;

(...)

15.11) implantar, no prazo de 1 (um) ano de vigência desta Lei, política nacional de formação continuada para os (as) profissionais da educação de outros segmentos que não os do ma- 
gistério, construída em regime de colaboração entre os entes federados;

(...)

16.2) consolidar política nacional de formação de professores e professoras da educação básica, definindo diretrizes nacionais, áreas prioritárias, instituições formadoras e processos de certificação das atividades formativas;

\section{$(\ldots)$}

19.2) ampliar os programas de apoio e formação aos (às) conselheiros (as) dos conselhos de acompanhamento e controle social do Fundeb, dos conselhos de alimentação escolar, dos conselhos regionais e de outros e aos (às) representantes educacionais em demais conselhos de acompanhamento de políticas públicas, garantindo a esses colegiados recursos financeiros, espaço físico adequado, equipamentos e meios de transporte para visitas à rede escolar, com vistas ao bom desempenho de suas funções;

(...)

19.5) estimular a constituição e o fortalecimento de conselhos escolares e conselhos municipais de educação, como instrumentos de participação e fiscalização na gestão escolar e educacional, inclusive por meio de programas de formação de conselheiros, assegurando-se condições de funcionamento autônomo;

\section{(...)}

19.8) desenvolver programas de formação de diretores e gestores escolares, bem como aplicar prova nacional específica, a fim de subsidiar a definição de critérios objetivos para o provimento dos cargos, cujos resultados possam ser utilizados por adesão.(...)" (BRASIL, 2014).

Desse modo, ao analisar a atual legislação concernente à formação docente percebemos que há em curso, pelo menos em teoria, a relevância dessa temática, sugerindo não haver necessidade de novos projetos de lei referindo-se ao tema.

Pelo apresentado no PNE, mesmo com a inclusão da estratégia 7.25 que trata diretamente da garantia de políticas de combate à violência na escola, com iniciativas voltadas à capacitação de educadores nessa temática, parece existir um problema de interpretação e entendimento por parte de legisladores quando não há uma menção clara de uma formação a respeito do bullying, escrito em formato de lei. Também se observa que, se refletirmos de modo ampliado, considerando as necessidades sociais e econômicas do país como exposto na estratégia 12.11, compreende-se que a formação nesse aspecto contempla (ria) o conhecimento na prevenção de violência na escola de modo amplo. Nesse sentido interpretativo, temos PLs categorizados em "formação" que não nos trazem novos aportes, apenas reverberam novas possibilidades linguísticas para um tema que foi legislado e que, até o presente momento, não vem sendo implementado.

A respeito da categoria 'informatização', alguns PLs trazem essa marca, seja na menção da produção de relatórios sobre os casos de bullying no âmbito escolar como é o caso do PL 350/2011, em que todas as unidades escolares do território nacional deverão apresentar relatórios bimestrais das ocorrências do bullying ou como propõe o PL 908/2011, em que "as ocorrências de "bullying" devem ser registradas pela Instituição de Ensino, em livro-ata próprio para esse fim, com data, hora, tipo de agressividade, indicação do nome do agressor e agredido e as providências tomadas" (IZAR, 2011), ou ainda com a instituição de um serviço de atendimento telefônico que receba denúncias anônimas sobre bullying como propõe o PL 2048/2011, apenas para citar três das oito referências dessa categoria.

Importante dizer que é válida a iniciativa de registro da ocorrência do bullying no âmbito da gestão escolar e mesmo nos órgãos municipais, estaduais e até mesmo federais, para fins numéricos de ocorrência e controle social, inclusive da implantação das leis já existentes de prevenção à violência. Entretanto, a atual Lei 13185 de 2015, em seu Art.6º já preconiza que "serão produzidos e publicados relatórios bimestrais das ocorrências de intimidação sistemática (bullying) nos Estados e Municípios para planejamento das ações" (BRASIL, 2015). Porém, temos uma ausência de fiscalização e monitoramento desse artigo como Palhares e Toledo (2017) informam.

Ademais, existem alguns desafios que antecedem esse procedimento: o juízo moral e a compreensão dos profissionais a respeito do bullying e a ausên- 
cia e unidade de formato para um controle total dessas ocorrências a fim de se obter um número mensal, bimestral, semestral ou anual sobre o fenômeno, nos aspectos circunscritos à territorialidade. Se tomarmos em conta que, hoje, não existe um sistema nacional que congregue, por exemplo, o andamento de todas as ocorrências que os Conselhos Tutelares acompanham e/ ou um sistema que reúna todos os casos de desaparecimentos de crianças e adolescentes no país, duas prioridades da área de defesa de direitos da infância e adolescência, o questionamento que se pode fazer em termos de compilação de dados é: Em vista da ausência de informatização que diz respeito à defesa e promoção dos direitos da infância e da adolescência, por que não se propõe em termos legislativos um PL que vise a criação de uma Base Nacional de Informações da Criança e do Adolescente, a exemplo de um DATASUS, agrupando informações de violações de direitos, de números de processos em andamento nas Varas da Infância e Juventude, de dados e categorias trabalhadas pelos Conselhos Tutelares, de convergência de informações sobre saúde, educação e assistência social, números de desaparecidos (contando com informações oriundas dos órgãos de segurança e justiça de cada Estado), números de crianças e adolescentes com doenças crônicas e deficiências, entre outras inúmeras informações referentes a esse público, em seus contornos municipais e estaduais, para um levantamento dessas e outras questões em âmbito nacional. Assim como a Receita Federal está conectada a uma série de dados tecnológicos que possibilitam saber se um contribuinte está em dia ou não com seus impostos devido à interface com outros sistemas, há tecnologia para que se crie esse arcabouço informacional no que diz respeito não só ao bullying, mas a toda e qualquer violação que ocorra com crianças e adolescentes, em espaços escolares ou não. Diante do conteúdo oferecido pelos PLs apresentados, notamos que os mesmos são reduzidos em suas respectivas potencialidades por considerarem apenas um pequeno aspecto da grande variedade de situações que necessitam de registro com o intuito de motivar políticas públicas de combate à violência e violações de direitos.

Referente à responsabilização e a penalização dos sujeitos que praticam bullying, essas últimas duas categorias analíticas foram encontradas em 12
PLs, sendo que dois são focados exclusivamente na penalização (PL 1011/2011 e PL 1494/2011), um (PL 1573/2011) confere a responsabilização e a penalização a depender do público envolvido, outros dois (PL 3686/2015 e PL 9243/2017) são exclusivos na categoria responsabilização e sete (PL 7457/2010, PL 350/2011, PL 908/ 2011, PL 1226/2011, PL 1633,2011, PL 3036/2011, PL 4805/2016), são 'multicategorias', visto que visam à responsabilização, mas também na formação, sensibilização etc.

A categoria 'penalização' refere-se às alterações no Código Penal, prioritariamente; já a responsabilização refere-se às alterações no Estatuto da Criança e do Adolescente e outras formas de imputar responsabilidades aos agressores.

A seguir, seguem os conteúdos das duas proposições referentes à penalização e, em seguida, excertos dos nove PLs restantes que trazem conteúdos sobre a responsabilização:

"Art $1^{\circ}$ O Decreto-Lei n ${ }^{\circ} 2.848$, de 7 de dezembro de 1940, passa a vigorar com a seguinte redação.

"Capítulo V: DOS CRIMES CONTRA A HONRA Intimidação escolar

Art. 141-A - Intimidar o indivíduo ou grupo de indivíduos que de forma agressiva, intencional e repetitiva, por motivo torpe, cause dor, angústia ou sofrimento, ofendendo sua dignidade em razão de atividade escolar ou em ambiente de ensino: Pena - detenção de um mês a seis meses e multa.

$\S 1^{\circ} \mathrm{O}$ Juiz pode deixar de aplicar a pena: I - quando o ofendido, de forma reprovável, provocou diretamente a intimidação.

$\S 2^{\circ}$ Se a intimidação consiste em violência ou vias de fato, que por sua natureza ou pelo meio empregado, se considerarem aviltantes: Pena detenção de três meses a um ano e multa, além da pena correspondente à violência.

$\S 3^{\circ}$ Se a intimidação tem a finalidade de atingir a dignidade da vítima ou vitimas pela raça, cor, etnia, religião, origem ou a condição de pessoa idosa ou que seja portadora de deficiência: Pena - reclusão de dois a quatro anos e multa.

$\S 4^{\circ}$ Considera-se intimidação escolar, para os efeitos penais as atitudes agressivas, 
intencionais e repetitivas, adotadas por um indivíduo intimidador ou grupo de indivíduos intimidadores contra outro(s) indivíduo(s), sem motivação evidente, causando dor, angústia ou sofrimento e, executadas em uma relação desigual de poder, o que possibilita a caracterização da vitimização" (FARIA, 2011).

"Art. $2^{\circ}$ O Decreto-Lei 2.848 , de 7 de dezembro de 1940 - Código Penal, passa a vigorar acrescido dos seguintes arts. 136-A, 136-B e 136-C: "Intimidação vexatória Art. 136-A. Intimidar, ameaçar, constranger, ofender, castigar, submeter, ridicularizar, difamar, injuriar, caluniar ou expor pessoa a constrangimento físico ou moral, de forma reiterada.

Pena - reclusão de 2 (dois) a 4 (quatro) anos e multa.

$\S 1 .^{\circ}$ Se o crime ocorre em ambiente escolar, a pena é aumentada da metade.

§2. Se há concurso de autores a pena é aumentada de $1 / 3$ (um terço).

$\S 3 .^{\circ}$ Incorre nas mesmas penas do $\$ 1 .^{\circ}$ o diretor do estabelecimento de ensino onde é praticado o crime que deixa de tomar as providências necessárias para fazer cessar a intimidação vexatória.

§4. ${ }^{\circ}$ Se o crime é praticado por meio de comunicação de massa, a pena é aumentada de $2 / 3$ (dois terços).

§5. Se a vítima é deficiente físico ou mental, menor de 14 (catorze) anos ou o crime ocorre explicitando preconceito de raça, cor, religião, procedência nacional, gênero, orientação sexual ou aparência física a pena se aplica em dobro. Intimidação vexatória qualificada

Art. 136-B. Se do crime definido no artigo anterior resulta: I - lesão corporal ou sequela psicológica grave, a pena é de reclusão de 4 (quatro) a 6 (seis) anos II - lesão corporal ou sequela psicológica permanente, a pena é de reclusão de 6 (seis) a 8 (oito) anos Intimidação vexatória seguida de morte

Art. 136-C. Se da intimidação resulta morte: Pena - reclusão de 12 (doze) a 30 (trinta) anos." 3 Art. $3 .^{\circ} \mathrm{O}$ art. 122 , parágrafo único, do Decreto
-Lei $n^{\circ} 2.848$, de 7 de dezembro de 1940, passa a vigorar acrescido do seguinte inciso III: "Art. 122

Parágrafo único III - se o suicídio resulta de atos de intimidação vexatória" (ABE, 2011).

“(...) Art. $3^{\circ}$ No âmbito de cada instituição a que se refere a esta Lei, a política "anti-bullying" terá como objetivos: (...) VII - orientar as vítimas de "bullying" e seus familiares, oferecendo-lhes os necessários apoios técnicos e psicológicos, de modo a garantir a recuperação da autoestima das vítimas e a minimização dos eventuais prejuízos em seu desenvolvimento escolar; VIII - orientar os agressores e seus familiares, a partir de levantamentos específicos, caso a caso, sobre os valores, as condições e as experiências prévias - dentro e fora das instituições de que trata esta Lei - correlacionadas à prática do "bullying", de modo a conscientizá-los a respeito das consequências de seus atos e a garantir o compromisso dos agressores com um convívio respeitoso e solidário de solidário com seus pares; IX - evitar tanto quanto possível a punição dos agressores, privilegiando mecanismos alternativos como, por exemplo, os "círculos restaurativos", a fim de promover sua efetiva responsabilização e mudança de comportamento; $X$ - envolver as famílias no processo de percepção, acompanhamento e formulação de soluções concretas; e XI - incluir no regimento a política "anti-bullying" adequada ao âmbito de cada instituição (...)" (VIDIGAL, 2010).

"São objetivos do Programa de Combate ao Bullying Escolar: (...) f) elaborar mecanismos que promovam a responsabilização objetiva da Instituição de Ensino, bem como do agressor; (...)" (AGUIAR, 2011).

"Art. $1^{\circ}$ As instituições de ensino públicas ou privadas, com ou sem fins lucrativos, no País ficam condicionadas à política "anti-bullying", nos termos desta Lei.

Art. $3^{\circ}$ No âmbito de cada instituição a que se refere esta Lei, a política "anti-bullying" tem como objetivos: (...) IX - evitar tanto quanto possível a 
punição dos agressores, privilegiando mecanismos alternativos como, por exemplo, os "círculos restaurativos", a fim de promover sua efetiva responsabilização e mudança de comportamento; $X$ - envolver as famílias no processo de percepção, acompanhamento e formulação de soluções concretas; (...)" (IZAR, 2011).

"Art. $1^{\circ}$ Ficam as escolas públicas e privadas de educação infantil, e de ensino fundamental e médio a instituir e manter Comissão Anti-Bullying composta paritariamente por membros de seu corpo docente e por pais e mães de alunos ou de seus responsáveis. Art. $2^{\circ} \mathrm{A}$ Comissão tem as seguintes competências: I - elaborar e divulgar plano de prevenção à prática de bullying, junto aos alunos, pais, mães e responsáveis pelos alunos; II - elaborar plano de repressão ao bullying, prevendo a intervenção imediata para o fim da ocorrência, incluindo: a suspensão dos agressores e a proteção explícita aos alunos vítimas; a notificação imediata aos pais ou responsáveis pelos alunos agressores e alunos vítimas e, em casos graves, o encaminhamento do alunos envolvidos ao Conselho Tutelar; III - receber reclamações e denúncias, relativas à prática de bullying, da parte de pais e mães de alunos ou de seus responsáveis, bem como dos próprios alunos; IV - prestar informações semestralmente ao órgão executivo de educação competente, bem como a todos os pais e mães de alunos ou seus responsáveis, sobre os trabalhos da Comissão, incluindo o número de ocorrências de bullying e os procedimentos adotados para a repressão. Parágrafo único: Em qualquer caso, os pais e mães dos alunos envolvidos ou seus responsáveis serão avisados pela escola sobre a participação de seus filhos na ocorrência do bullying, como agressores e vítimas, e chamados para reunião conjunta, com a mediação da Comissão Anti-Bullying, em busca de uma solução conjunta.

Art. $3^{\circ} \mathrm{Em}$ caso de descumprimento dos artigos $1^{\circ}$ e $2^{\circ}$ desta Lei a escola particular será autuada pelo órgão executivo de educação competente, com multa administrativa no valor correspondente a vinte das maiores mensalidades cobradas no ano dentre outras penalidades administrativas. Parágrafo único: Os recursos arrecadados com as multas serão revertidos para a educação pública.

Art. $4^{\circ}$ As escolas públicas que descumprirem os artigos $1^{\circ}$ e $2^{\circ}$ desta Lei serão autuadas com penalidades administrativas pelo órgão executivo de educação competente, na forma do regulamento (...)" (RIBEIRO, 2011).

"Art. $1^{\circ}$ Esta lei acrescenta dispositivo à Lei $\mathrm{n}^{\circ}$ 8.069, de 13 de julho de 1990 - Estatuto da Criança e do Adolescente, dispondo sobre o direito da criança e do adolescente à retratação, pelo mesmo meio, em caso de "bullying" virtual. Art. $2^{\circ} \mathrm{O}$ art. 17 da Lei $\mathrm{n}^{\circ} 8.069$, de 13 de julho de 1990, passa a vigorar acrescido do seguinte parágrafo único:

"Art. 17. Parágrafo único. A criança e o adolescente, vítimas de "bullying" virtual, têm direito à retratação do agressor pelo mesmo meio em que $\mathrm{o}$ ato de violência psicológica foi praticado (NR)" (SHÉRIDAN, 2015a).

"Art. $1^{\circ}$ Esta Lei tipifica o crime de intimidação sistemática (Bullying), prevendo causa de aumento se a conduta for realizada por meio da internet (Cyberbullying).

Art. $2^{\circ} \mathrm{O}$ Decreto-Lei $\mathrm{n}^{\circ} 2.848$, de 7 de dezembro de 1940, passa a vigorar acrescido do seguinte artigo: "Art.141-A - Intimidar intencionalmente e repetitivamente indivíduo ou grupo de indivíduos por meio de violência física ou psicológica, causando dor e angústia à vítima. Pena - detenção de um mês a seis meses e multa. Parágrafo único: Se o meio utilizado para a prática da intimidação sistemática (Bullying) for a internet, a pena será aumenta de um terço. (NR)

Art. $3^{\circ}$. Esta lei entra em vigor na data de sua publicação" (CARLETTO, 2015).

"Art. $1^{\circ}$. Esta Lei altera a Lei $n^{\circ} 13.185$, de 6 de novembro de 2015, para dispor sobre a Perseguição Sistemática Digital (cyberstalking) e dar outras providências. (...) Art. $4^{\circ}$. A o artigo $4^{\circ}$, da Lei $n^{\circ} 13.185$, de 6 de novembro de 2015, passa a vigorar com a seguinte redação: "Art. $4^{\circ}$. 
I - prevenir e combater a prática da intimidação sistemática (bullying) e da perseguição sistemática (stalking) em toda a sociedade;

VIII - privilegiar mecanismos e instrumentos alternativos que promovam a efetiva responsabilização e a mudança de comportamento hostil (...)" (FLAVINHO, 2016)

"Art. $1^{\circ}$ Esta Lei altera a redação da Lei $n^{\circ}$ 13.185, de 6 de novembro de 2015, que institui o Programa de Combate à Intimidação Sistemática (Bullying), para prever medidas coercitivas a quem pratica violência contra crianças e adolescentes no ambiente escolar.

Art. $2^{\circ} \mathrm{O}$ inciso VIII, do art. $4^{\circ}$, da Lei $\mathrm{n}^{\circ} 13.185$, de 6 de novembro de 2015, passa a vigorar com a seguinte redação:

"Art $4^{\circ}$

VIII - promover a responsabilização dos agressores na devida medida do ato cometido;

"(NR)

Art. $3^{\circ}$ Acrescente-se o seguinte art. $7^{\circ}$-A à Lei $n^{\circ}$ 13.185, de 6 de novembro de 2015: "Art. $7^{\circ}$-A Entre outras medidas, os estabelecimentos de ensino devem priorizar: I - a solicitação de que o Ministério Público acompanhe os casos ocorridos; 2 II - a presença da força policial e de serviços públicos como saúde, assistência social ou demais serviços especializados de segurança pública, para evitar e prevenir violência nas escolas; III - a adoção de medidas administrativas e jurídicas cabíveis contra qualquer irregularidade constatada que coloque em risco a integridade de crianças, adolescentes e dos demais atores escolares" (ROCHA, 2017).

"Art. $1^{\circ}$ - Esta lei acrescenta o art. 140-A ao Decreto-lei n. ${ }^{\circ}$ 2.848, de 7 de dezembro de 1940 - Código Penal, e o art. 117-A à Lei n. ${ }^{\circ}$ 8.069, de 13 de julho de 1990, que "dispõe sobre o Estatuto da Criança e do Adolescente e dá outras providências", a fim de tipificar o crime de "bullying". Art. $2 .^{\circ}$. O Decreto-lei n. 2.848 , de 7 de dezembro de 1940, passa a vigorar acrescido do seguinte art. 140-A:

"Bullying Art. 140-A. Ofender reiteradamente a integridade moral ou física de outrem, com o intuito de causar-Ihe constrangimento público ou zombaria.

Pena - reclusão, de um a quatro anos, e multa. Aumento de Pena - Parágrafo único. Se o crime for cometido por mais de uma pessoa, por meio eletrônico ou por qualquer mídia, o juiz pode aumentar a pena de um sexto a um terço."

Art. 3. ${ }^{\circ}$. A Lei n. ${ }^{\circ} 8.069$, de 13 de julho de1990, passa a vigorar acrescida do seguinte artigo 117-A:

"Art. 117-A. Verificada a prática de conduta descrita como "bullying", a autoridade competente aplicará ao adolescente a medida de prestação de serviços à comunidade". (LIRA, 2011).

Algumas das proposições legislativas acima buscam responsabilizar ou penalizar o sujeito que pratica bullying, sugerindo alterações na Lei No. 8069, de 13 de julho de 1990, e no Decreto-Lei No. 2848, de 7 de dezembro de 1940, Estatuto da Criança e do Adolescente e Código Penal, respectivamente. Outras apoiam-se na responsabilização por meio de círculos restaurativos $^{13}$, ou pela atuação do Conselho Tutelar, ou até mesmo encaminhando a situação ao Ministério Público. Além dessas, há também possibilidade subjetiva de responsabilização deixando a cargo da gestão escolar para a tomada de providências, tendo em vista que a escola pode sofrer penalizações dos órgãos competentes educacionais caso descumpram a legislação referida. De algum modo, parlamentares buscam responsabilizar ou penalizar quem pratica bullying.

Desde 1990 crianças e adolescentes são sujeitos de direito, quando foi sancionado o Estatuto da Criança e do Adolescente (BRASIL, 1990). A Lei 8069 de 1990 preconiza em seus Artigos 3, 4, 15, 18 e 208 (Inciso XI) que a criança e o adolescente têm assegurados a efetivação do direito à dignidade, sendo dever da família, da comunidade, da sociedade em geral e do poder público priorizar de modo absoluto a efetivação dos direitos referentes ao respeito em todas as suas instâncias.

Crianças e adolescentes autores de ato infracional, isto é, que agem com uma conduta descrita como crime ou contravenção penal, contam com

13 Vale observar que os PLs 7457/2010 e 908/2011 contam com a mesma redação a respeito dos círculos restaurativos. 
os Artigos 98, 99, 100, 101 e 102 para medidas de proteção e os Artigos 103 ao 128 para medidas socioeducativas referentes aos atos infracionais praticados por adolescentes, visto que a criança menor de 12 anos conta com o Art. 101 para as tratativas. Os Artigos 129 e 130, por sua vez, direcionam penalidades aos pais, mães e responsáveis de crianças e adolescentes, sendo autores de ato infracional ou não.

Quando da existência de provas suficientes da prática de ato infracional, o Art. 112 do ECA prevê a aplicação de medidas socioeducativas pela autoridade competente. São elas: advertência; obrigação de reparar o dano; prestação de serviços à comunidade; liberdade assistida; inserção em regime de semiliberdade; internação em estabelecimento educacional; e qualquer uma das previstas no art. 1014 ${ }^{14}$, a VI (BRASIL, 1990).

A injúria é uma atribuição de uma qualidade negativa ofensiva que atinge a dignidade de outrem e o Decreto-Lei No. 2848, de 7 de dezembro de 1940, Código Penal, por sua vez, estabelece em seu Art.140 que "injuriar alguém, atendendo-lhe a dignidade ou o decoro" (BRASIL, 1940), fará o agressor ter uma pena de detenção, de um a seis meses, ou multa. O juiz poderá deixar de aplicar a pena quando o ofendido, de forma reprovável, provocou diretamente a injúria e no caso de retorsão imediata, que consista em outra injúria. Em seu $\S 2^{\circ}$, do mesmo artigo, tem-se que, "Se a injúria consiste em violência ou vias de fato, que, por sua natureza ou pelo meio empregado, se considerem aviltantes" (Idem), a pena é também a detenção, de

14 "Art. 101. Verificada qualquer das hipóteses previstas no art. 98, a autoridade competente poderá determinar, dentre outras, as seguintes medidas: I- encaminhamento aos pais ou responsável, mediante termo de responsabilidade; II- orientação, apoio e acompanhamento temporários; IIImatrícula e freqüência obrigatórias em estabelecimento oficial de ensino fundamental; IV- inclusão em serviços e programas oficiais ou comunitários de proteção, apoio e promoção da família, da criança e do adolescente (Redação dada pela Lein ${ }^{\circ} 13.257$, de 2016); V-requisição de tratamento médico, psicológico ou psiquiátrico, em regime hospitalar ou ambulatorial; VI- inclusão em programa oficial ou comunitário de auxílio, orientação e tratamento a alcoólatras e toxicômanos; VII- acolhimento institucional (Redação dada pela Lei $n^{\circ} 12.010$, de 2009); VIII- inclusão em programa de acolhimento familiar (Redação dada pela Lei $n^{\circ} 12.010$, de 2009); IX- colocação em família substituta” (BRASIL, 1990). três meses a um ano, e multa, além da pena correspondente à violência.

Devemos recordar que o bullying para ser reconhecido como tal precisa contar com as três características mencionadas por Olweus (2011): comportamento negativo, repetitividade e dificuldade de defesa da vítima. De certa maneira, a injúria sendo reiterada com alguma frequência e, sendo a vítima uma criança ou adolescente, pela legislação atual é possível dizer que os artigos acima mencionados no ECA e no Código Penal caberiam na penalização e/ou responsabilização em defesa da criança e adolescente ou em sua respectiva responsabilização, pois oferecem subsídios para se pensar a respeito da dignidade desses sujeitos em ambientes escolares ou fora deles, sendo provocados por outras pessoas de mesma idade ou adultos, ainda que possamos e devamos pensar as razões e o contexto em que a prática acontece e como ela ocorre, com o intuito de compreender o cenário em que se encontra o agressor a fim de coibir as causas e não somente responsabilizar as consequências.

No que se refere à atuação do Conselho Tutelar (CT), a atual legislação também é clara quanto à proteção de crianças e adolescentes. O Art. 136 do ECA já apresenta as atribuições do CT nas hipóteses previstas nos arts. 98 e 105, aplicando medidas previstas no art. 101, I a VII, além de poder "encaminhar ao Ministério Público notícia de fato que constitua infração administrativa ou penal contra os direitos da criança ou adolescente" (BRASIL, 1990) e "encaminhar à autoridade judiciária os casos de sua competência" (idem). Para o adolescente autor de ato infracional, o CT tem como atribuição providenciar a medida definida pela autoridade judiciária, dentre as previstas no art. 101, de I a VI, para esse adolescente, além de promover e incentivar, em todos os locais de atuação, o reconhecimento de sintomas de maus-tratos em crianças e adolescentes ${ }^{15}$.

Sobre as atribuições do Ministério Público (MP), a Constituição Federal de 1988 determinou a ele a "defesa da ordem jurídica, do regime democrático e dos interesses sociais e individuais indisponíveis" (BRA-

15 Trecho incluído pela Lei No.13.046, de 2014, que altera a Lei № 8.069, de 13 de julho de 1990, que "dispõe sobre o Estatuto da Criança e do Adolescente e dá outras providências", para obrigar entidades a terem, em seus quadros, pessoal capacitado para reconhecer e reportar maus-tratos de crianças e adolescentes". 
SIL, 1988). De acordo com a Associação Nacional dos Membros do Ministério Público (CONAMP, 2017), "os interesses sociais são aqueles difusos e coletivos: meio ambiente; patrimônio histórico, turístico e paisagístico; consumidor; portadores de deficiência; criança e adolescente, comunidades indígenas e minorias étnico-sociais" e os interesses individuais indisponíveis são aqueles próprios de cada pessoa, contudo com relevância pública. Desse modo, pelo apresentado acima, tanto o CT quanto o MP têm entre suas atribuições a promoção e a defesa dos direitos da criança e do adolescente quanto a sua integridade e dignidade.

Assim, a partir dos enunciados das legislações referidas e das proposições legislativas em tramitação especificadas nas categorias responsabilização e penalização, é possível perceber que o que se quer apresentar de novo em termos de projeto de lei é a inclusão do termo bullying em artigos do ECA ou do Código Penal. Em miúdos, o que parece ser posto pelos PLs inscritos nessa categoria é uma intenção de escrever por extenso o bullying dentro da norma jurídica, como se a ausência do termo nas referidas legislações não estivesse contemplado a partir dos termos injúria e/ou violência que existem nas normas. Ou seja, como se a falta do vocábulo 'bullying' não fosse contemplado por outros artigos que tratam sobre agressão, violência moral, etc., ou ainda que, pelo fato de não estar subscrito dentro da norma, não houvesse parâmetro para o entendimento de que uma injúria proferida repetidamente, sem que exista defesa da vítima, possa ser enquadrada numa tipologia criminal e que a violência física contra crianças e adolescentes já não fosse legislada.

Além disso, diante do tamanho da população encarcerada no país, das violações dos direitos humanos de presos e presas, dos desafios da incompletude da implementação do Sistema Nacional de Atendimento Socioeducativo (SINASE), do número de adolescentes autores de ato infracional que têm também seus direitos violados e das últimas investidas dos órgãos de segurança pública dentro de escolas e contra adolescentes de forma não pacífica, uma possível reflexão a partir disso é pensar se há um movimento político ideológico de criminalização da adolescência e, principalmente, da adolescência negra, periférica e pobre, visto que os dados do sistema penitenciário e socioeducativo comprovam que é o jovem negro quem ocupa majoritariamente esses espaços (PASTORAL CARCERÁRIA, 2018; SINASE, 2018). Também é legítimo questionar se penalizar instituições públicas de ensino que não têm recebido o devido reconhecimento em seus múltiplos aspectos e os respectivos investimentos para realizar uma educação pública de qualidade por conta da não efetivação do Plano Nacional de Educação e da retração de investimentos nas áreas sociais resolveria de modo eficaz a problemática na qual a escola se insere. Por fim, faz-se salientar, para além dos círculos restaurativos, quais outras possibilidades de intervenção poderiam ser adotadas, ao invés de cárcere e medida socioeducativa de internação com fins de penalização e responsabilização da prática de bullying no atual contexto em que vivemos?

Desse modo, foi possível observar no decorrer das análises acima, que as proposições legislativas em tramitação não inovam na solução do problema 'bullying' junto ao público infanto-juvenil, nem ao que se refere em marcos jurídicos, visto que as atuais legislações já contemplam os enunciados a partir de uma compreensão ampliada do já proposto e em vigor.

\section{Considerações finais}

Buscamos apresentar ao longo deste texto o conceito de bullying, suas interfaces sociais no âmbito da infância e da adolescência, a metodologia de pesquisa sobre as proposições legislativas em tramitação no Congresso Nacional, as categorias de análise do conteúdo apresentado na ementa dos PLs no que concerne as possíveis mudanças nas atuais normativas legais existentes no país sobre bullying junto a crianças e adolescentes, principalmente, referendando o espaço escolar.

A partir de seis categorias (formação, mudanças na LDB, informatização, sensibilização, responsabilização e penalização), constatou-se: 1- a categoria sensibilização esteve presente em 18 das 28 proposições legislativas, sendo que a atual legislação contempla a implementação de campanhas de sensibilização à população; 2- os PLs da categoria 'formação' e 'mudanças na LDB', sendo sete propostas registradas em cada uma destas, não oferecem novos aportes legais, apenas reverberam novas possibilidades linguísticas para um tema já legislado; 3- a atual lei que institui 
- Programa de Combate à Intimidação Sistemática (bullying) informa que os Estados e Municípios deverão produzir relatórios das ocorrências, no entanto, há ausência de monitoramento desse item nas políticas públicas estaduais e municipais, consequentemente, não há dados federais sobre a prática; 4- os 12 PLs contemplados nas categorias 'responsabilização' e 'penalização' buscam incluir o bullying como ato infracional e/ou crime a depender da idade do/ da praticante de intimidação sistemática, porém, as atuais legislações - ECA e Código Penal - já contemplam em diversos de seus artigos o crime de injúria e/ ou violência física, sendo que as propostas como estão sendo colocadas, em sua maioria, criminalizariam a infância e a adolescência.

Também podemos observar que, de modo geral, os PLs em tramitação não oferecem substanciais e novos conteúdos diante da legislação da infância e da adolescência, bem como no tocante às leis da área da Educação. O país possui um arcabouço jurídico que contempla, ainda que de forma não implementada, a prevenção e o combate ao bullying, porém, para além das atribuições referentes às funções do Poder Legislativo federal, o Congresso Nacional também deveria exercer as atribuições de fiscalização e controle (BRASIL, s/d (a)). Nesse sentido, ao que tudo indica, é preciso que a Câmara dos Deputados passe a desenvolver melhor sua respectiva atribuição de controlar e fiscalizar o que as leis em vigor recomendam antes de criar novos projetos de lei que, ao fim e ao cabo, são mais do mesmo da velha política.

Por fim, vale salientar que este artigo não exaure as diversas possibilidades de novos estudos nas mais diversas áreas científicas da linguagem, do sujeito e da sociedade sobre as proposições legislativas mencionadas e suas justificativas como àquelas novas que virem a tramitar no que se refere ao bullying, violência escolar, militarização nas escolas, criminalização da infância e da adolescência, Seguramente, com novos aportes, horizontes sobre o modo como se tem feito política e leis para crianças e adolescentes poderão ser ampliados a partir e no âmbito da Educação e das Ciências Humanas e Sociais.

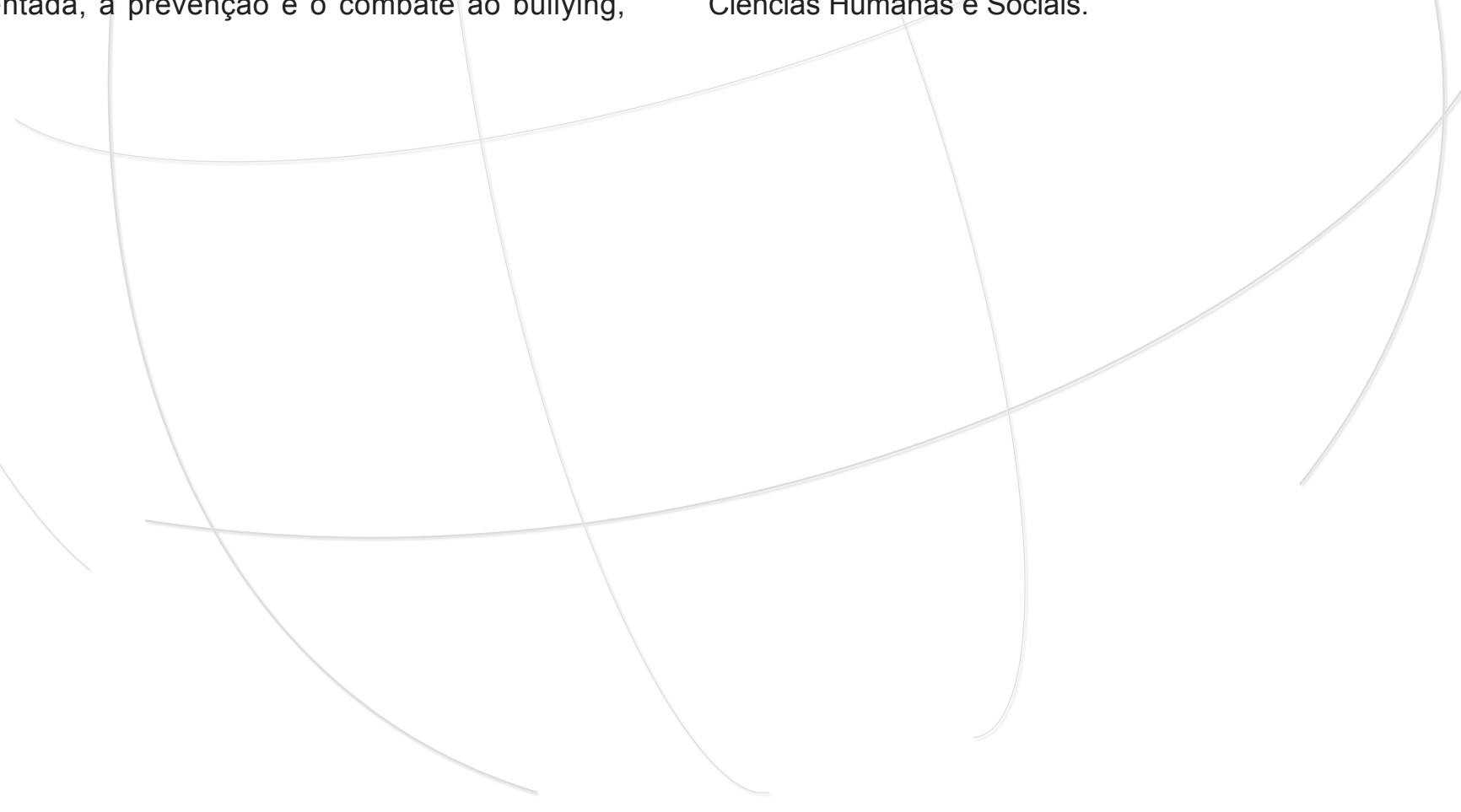




\section{REFERÊNCIAS}

ABE, J. Projeto de Lei No. 1494, de 2011. Brasília: Câmara dos Deputados, 2011. Disponível em: https://www.camara.leg.br/proposicoesWeb/prop_mostrarintegra?codteor $=880669$ \&filename $=P L+1494 / 2011$ Acesso em: 01 mar. 2019.

ADORNO, S. O Massacre de Realengo. São Paulo: Le Monde Diplomatique, 2011. Disponível em: https://diplomatique.org.br/o-massacre-de-realengo/. Acesso em 15 mar. 2019.

AGUIAR, M. Projeto de Lei No. 350, de 2011. Brasília: Câmara dos Deputados, 2011. Disponível em: https://www.camara.leg.br/proposicoesWeb/propmostrarintegra?codteor $=838788$ \&filename $=P L+350 / 2011$. Acesso em: 01 mar. 2019

ARGELLO, G. Projeto de Lei No. 1785, de 2011. Brasília: Senado Federal, 2011. Disponível em: https:// www.camara.leg.br/proposicoesWeb/propmostrarintegra? codteor $=896943 \&$ filename $=P L+1785 / 2011$. Acesso em: 01 mar 2019.

ASSOCIAÇÃO NACIONAL DOS MEMBROS DO MINISTÉRIO PÚBLICO - CONAMP. Entenda o que é o Ministério Público e como funciona. Brasília: CONAMP, s/d. Disponível em: https://www.conamp. org.br/blog/entenda-o-que-e-o-ministerio-publico-e-como-funcional. Acesso em: 01 abr. 2019.

BAKHTIN, Mikhail. Marxismo e filosofia da linguagem: problemas fundamentais do método sociológico da linguagem. 14. ed. São Paulo: Hucitec, 2010.

BARONE, Isabelle. Suzano, Realengo, Columbine: quando o bullying pode terminar em tragédia. Gazeta do Povo. Curitiba, 14 mar 2019. Disponível em https://www.gazetadopovo.com.br/educacao/suzano -realengo-columbine-bullying-nao-resolvido-pode-resultar-em-tragedial. Acesso em: 15 mar. 2019.

BRASIL. Câmara dos Deputados. Bancada feminina na Câmara sobe de $\mathbf{5 1}$ para $\mathbf{7 7}$ deputadas. Brasília: Câmara dos Deputados, 2018. Disponível em: https://www2.camara.leg.br/camaranoticias/noticias/ POLITICA/564035-BANCADA-FEMININA-NA-CAMARA-SOBE-DE-51-PARA-77-DEPUTADAS.html. Acesso em: 25 mar 2019.
. Ministério da Educação. Pacto Universitário pela Promoção do Respeito à Diversidade, da Cultura de Paz e dos Direitos Humanos. Brasília, s/d. Disponível em http://edh.mec.gov.br/pactol. Acesso em: 01 de abr. 2019.

Ministério dos Direitos Humanos. Secretaria Nacional dos Direitos da Criança e do Adolescente. Coordenação Geral do Sistema Nacional de Atendimento Socioeducativo. Levantamento Anual SINASE 2016. Brasília: MDH, 2018.

. Presidência da República. Casa Civil. Subchefia para Assuntos Jurídicos. Decreto-Lei No. 2.848, de 7 de dezembro de 1940. Rio de Janeiro, 7 Dez 1940. Disponível em: http://www.planalto.gov.br/ ccivil 03/decreto-lei/del2848.html. Acesso em: $01 \mathrm{abr}$. 2019.

. Constituição da República Federativa do Brasil de 1988. Brasília, 5 Out 1988. Disponível em: http://www.planalto.gov.br/ccivil 03/constituicao/constituicaocompilado.html. Acesso em: $01 \mathrm{abr}$. 2019.

Lei No. 8.069, de 13 de julho de 1990. Dispõe sobre o Estatuto da Criança e do Adolescente e dá outras providências. Brasília, 13 Jul 1990. Disponível em: http://www.planalto.gov.br/ccivil 03/ leis/18069.html Acesso em: 15 mar. 2019.

Lei No. 9.394, de 20 de dezembro de 1996. Estabelece as diretrizes e bases da educação nacional. Brasília, DF, 23 dez 1996. Disponível em: http://www.planalto.gov.br/ccivil 03/LEIS/L9394. html. Acesso em 15 mar. 2019.

Lei No. 13.005, de 25 de junho de 2014. Aprova o Plano Nacional de Educação - PNE e dá outras providências. Brasília, DF, 25 Jun 2014. Disponível em: http://www.planalto.gov.br/ccivil 03/ Ato2011-2014/2014/Lei/L13005.html. Acesso em: 25 mar. 2019.

Lei No. 13.185 , de 6 de novembro de 2015. Institui o Programa de Combate à Intimidação Sistemática (Bullying). Brasília, DF, 09 nov 2011. Disponível em: http://www.planalto.gov.br/ccivil_03/_ato2015-2018/2015/lei/l13185.html. Acesso em: 15 mar. 2019. 
Lei No. 13.277, de 29 de abril de

2016. Institui o dia 7 de abril como o Dia Nacional de Combate do Bullying e à Violência na Escola. Brasília, DF, 2 maio 2016. Disponível em: http://www.planalto. gov.br/ccivil_03/ato2015-2018/2016/lei/L13277.html Acesso em: 25 mar. 2019.

Lei No. 13.663, de 14 de maio de

2018. Altera o art. 12 da Lei $n^{\circ} 9.394$, de 20 de dezembro de 1996, para incluir a promoção de medidas de conscientização, de prevenção e de combate a todos os tipos de violência e a promoção da cultura de paz entre as incumbências dos estabelecimentos de ensino. Brasília, DF, 15 maio 2018. Disponível em: http:// www.planalto.gov.br/ccivil03/Ato2015-2018/2018/Lei/ L13663.htm. Acesso em: 15 mar. 2019.

BORNIER, F. Projeto de Lei No. 1633, de 2011. Brasília: Câmara dos Deputados, 2011. Disponível em: https://www.camara.leg.br/proposicoesWeb/fichadetramitacao?idProposicao=509806 Acesso em: 01 mar. 2019.

CARLETTO, R. Projeto de Lei No. 3686, de 2015. Brasília: Câmara dos Deputados, 2015. Disponível em: https://www.camara.leg.br/proposicoesWeb/ prop mostrarintegra?codteor $=1415345$ \&filena-

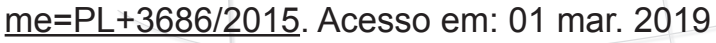

CERTEAU, Michel de. A invenção do cotidiano: 1 artes de fazer. Tradução de Ephraim Ferreira Alves. Petrópolis: Vozes, 1994.

CRISTALDO, H. Partidos formalizam três blocos parlamentares na Câmara. Brasília: Agência Brasil, 2019. Disponível em: http://agenciabrasil.ebc. com.br/politica/noticia/2019-02/partidos-formalizamtres-blocos-parlamentares-na-camara. Acesso em: 01 abr. 2019.

CONSELHO NACIONAL DE JUSTIÇA. CNJ lança cartilha de combate ao bullying em Brasília. Brasília: CNJ, 10 mar 2010. Disponível em: https://www.cnj.jus.br/cnj-lanca-cartilha-de-combate-ao -bullying-em-brasilial. Acesso em: 25 mar. 2019.

CNJ distribui 27 mil cartilhas a tribunais e escolas desde 2015. Brasília: CNJ, 20 jun 2018. Disponível em: http://www.cnj.jus.br/noticias/cnj/87022-cnj-distribui-27-mil-cartilhas-a-tribunais-e-escolas-desde-2015. Acesso em: 25 mar. 2019.
CORREIO BRAZILIENSE. Mãe de atirador de Suzano diz que adolescente sofria bullying na escola. Correio Braziliense. Brasília, 13 março 2019. Disponível em: https://www.correiobraziliense.com.br/ app/noticia/brasil/2019/03/13/interna-brasil,742768/ mae-de-atirador-de-suzano-diz-que-adolescente-sofria-bullying.shtml Acesso em: 18 Mar. 2019.

COSTA, L. Projeto de Lei No. 5612, de 2009. Brasília: Câmara dos Deputados, 2009. Disponível em https://www.camara.leg.br/proposicoesWeb/ prop mostrarintegra?codteor $=671030$ \&filename=PL+5612/2009 Acesso em: 01 mar. 2019.

FABIANO, D. Projeto de Lei No. 6504, de 2011. Brasília: Câmara dos Deputados, 2011. Disponível em: https://www.camara.leg.br/proposicoesWeb/propmostrarintegra?codteor $=1150607$ \&filena$\underline{m e}=P L+6504 / 2013$. Acesso em: 01 mar. 2019.

FANTE, C. Fenômeno Bullying: como prevenir a violência nas escolas e educar para a paz. $2^{a}$. ed. Campinas: Verus, 2005.

FARIA, F. Projeto de Lei No. 1011, de 2011. Brasília: Câmara dos Deputados, 2011. Disponível em: https://www.camara.leg.br/proposicoesWeb/propmostrarintegra? codteor $=858789$ \&filename $=P L+1011 / 2011$. Acesso em: 01 mar. 2019.

FLAVINHO. Projeto de Lei No. 4805, de 2016. Brasília: Câmara dos Deputados, 2016. Disponível em: https://www.camara.leg.br/proposicoesWeb/propmostrarintegra?codteor $=1445448$ \&filena$\underline{m e}=P L+4805 / 2016$. Acesso em: 01 mar 2019.

FRANCISCO, Marcos Vinicius; LIBORIO, Renata Maria Coimbra. Um estudo sobre bullying entre escolares do ensino fundamental. Psicol. Reflex. Crit, v. 22, n. 2, p. 200-207, 2009. DOI http://dx.doi. org/10.1590/S0102-79722009000200005. Disponível em: http://www.scielo.br/scielo.php?script=sci_arttext\&pid=S0102-79722009000200005\&lng=en\&nrm=iso. Acesso em: 21 mar. 2019.

IBGE - INSTITUTO BRASILEIRO DE GEOGRAFIA E ESTATÍSTICA. Pesquisa Nacional de Saúde do Escolar (PeNSE) 2009. Rio de Janeiro: IBGE. IBGE - Instituto Brasileiro de Geografia e Estatística, 2009. Disponível em: https://biblioteca. ibge.gov.br/visualizacao/livros/liv43063.pdf. Acesso em: 15 mar. 2019. 
. Pesquisa Nacional de Saúde do Escolar (PeNSE) 2012. Rio de Janeiro: IBGE. IBGE Instituto Brasileiro de Geografia e Estatística, 2012. Disponível em: https://biblioteca.ibge.gov.br/visualizacao/livros/liv64436.pdf. Acesso em: 15 mar. 2019.

Pesquisa Nacional de Saúde do

Escolar (PeNSE) 2015. Rio de Janeiro: IBGE. IBGE Instituto Brasileiro de Geografia e Estatística, 2015. Disponível em: https://biblioteca.ibge.gov.br/visualizacao/livros/livros97870.pdf. Acesso em: 15 mar. 2019.

INEP - INSTITUTO NACIONAL DE ESTUDOS E PESQUISAS EDUCACIONAIS ANISIO TEIXEIRA. Resumo Técnico: Censo da Educação Básica 2018 [recurso eletrônico]. Brasília: Instituto Nacional de Estudos e Pesquisas Educacionais Anísio Teixeira, 2019. Disponível em: http://download.inep.gov.br/educacao basica/censo escolar/resumos tecnicos/resumo tecnico_censo_educacao_basica2018.pdf. Acesso em: 25 mar. 2019.

IZAR, R. Projeto de Lei No. 908, de 2011. Brasília: Câmara dos Deputados, 2011. Disponível em: https://www.camara.leg.br/proposicoesWeb/propmostrarintegra? codteor $=856155$ \&filename $=P L+908 / 2011$. Acesso em: 01 mar. 2019.

LEITE, O; BARBOSA, E. Projeto de Lei No. 10.162, de 2018. Brasília: Câmara dos Deputados, 2018. Disponível em: https://www.camara.leg.br/proposicoesWeb/propmostrarintegra?codteor $=1656699$ \&filename $=P L+10162 / 2018$. Acesso em: 01 mar 2019

LIRA, A. Projeto de Lei No. 1573, de 2011. Brasília: Câmara dos Deputados, 2011. Disponível em: https://www.camara.leg.br/proposicoesWeb/propmostrarintegra?codteor=888516\&filename $=P L+1573 / 2011$. Acesso em: 01 mar 2019.

LOPES NETO, Aramis A. Bullying: comportamento agressivo entre estudantes. J. Pediatr, v. 81, n. 5, supl. p. s164-s172, nov. 2005. DOI: http://dx.doi. org/10.1590/S0021-75572005000700006. Disponível em: http://www.scielo.br/scielo.php?script=sci_arttext\&pid=S0021-75572005000700006\&lng=pt\&nrm=iso. Acesso em: 21 mar. 2019.

MABEL, S. Projeto de Lei No. 1226, de 2011. Brasília: Câmara dos Deputados, 2011. Disponível em: https://www.camara.leg.br/proposicoesWeb/propmostrarintegra?codteor $=865964$ \&filena$\underline{m e}=P L+1226 / 2011$. Acesso em: 01 mar 2019.
MARTINS, Helena. Mais conservador, Congresso eleito pode limitar avanços em direitos humanos. Agência Brasil. 9 Out. 2014. Disponível em: http:// agenciabrasil.ebc.com.br/politica/noticia/2014-10/ mais-conservador-congresso-eleito-pode-limitar-avancos-em-direitos-humanos. Acesso em: 25 mar. 2019.

MELLO, Flávia Carvalho Malta. et al. The practice of bullying among Brazilian schoolchildren and associated factors, National School Health Survey 2015. Ciênc. saúde coletiva, v. 22, n. 9, p. 29392948, Sept. 2017. DOI: http://dx.doi.org/10.1590/141381232017229.12762017. Disponível em: http:// www.scielo.br/scielo.php?script=sci_arttext\&pi$\mathrm{d}=\mathrm{S} 1413-81232017002902939 \& \mathrm{lng}=\mathrm{en} \& \mathrm{nrm}=$ iso. Acesso em 19 mar. 2019.

OLWEUS, D. Bullying at school: what we know and what we can do (understanding children's worlds). Oxford: Blackwell Publishing, 1993.

Bully/ victim problems in school: facts and intervention. European Journal of Psychology, v. 21, n. 4, p. 495-510, Dez. 1997. Disponível em: http://www.episcenter.psu.edu/sites/default/files/news/ Olweus\%20\%281997\%29\%20Bully-victim\%20problems\%20in\%20school.pdf. Acesso em: 19 mar. 2019. Bullying at school and later criminality: findings from three Swedish community samples of males. Criminal Behav. Ment. Health, v. 21, n.2, p. 151-156, abr. 2011. DOI 10.1002/cbm.806. Disponível em

https://onlinelibrary.wiley.com/doi/epdf/10.1002/ cbm.806. Acesso em: 19 mar. 2019.

School bullying: development and some important challenges. Annu Rev Clin Psychol, v. 9, p. 751-780, 2013. DOI 10.1146/annurev-clinpsy-050212-185516 Disponível em: https:// www.annualreviews.org/doi/full/10.1146/annurevclinpsy-050212-185516. Acesso em: 21 mar. 2019.

OTONI, R. Projeto de Lei No. 311, de 2019. Brasília: Câmara dos Deputados, 2019. Disponível em: https://www.camara.leg.br/proposicoesWeb/propmostrarintegra?codteor $=1707418$ \&filename $=P L+311 / 2019$. Acesso em: 01 mar 2019. 
PALHARES, I; TOLEDO, L F. Sem fiscalização, lei antibullying engatinha no Congresso. O Estado de São Paulo [online]. Brasil, 24 Out 2017. Disponível em: https://educacao.estadao.com.br/noticias/ geral,sem-fiscalizacao-lei-antibullying-engatinha-no -pais,70002057787. Acesso em 25 mar. 2019.

PASTORAL CARCERÁRIA NACIONAL - CNBB. Luta Antiprisional no mundo contemporâneo: um estudo sobre experiências de redução da população carcerária em outras nações. São Paulo, 2018. Disponível em: https://desencarceramento.org.br/wpcontent/uploads/2018/09/relatorio luta antiprisional. pdf. Acesso em 01 mar 2019.

REDAÇÃO RBA. Bolsonaro perde mais uma para a deputada Maria do Rosário. Rede Brasil Atual. [online]. 19 Fev. 2019. Disponível em: https://www. redebrasilatual.com.br/politica/2019/02/bolsonaro-perde-mais-uma-para-maria-do-rosario/ Acesso em 19 mar. 2019.

RIBEIRO, A. Projeto de Lei No. 3036, de 2011. Brasília: Câmara dos Deputados, 2011. Disponível em: https://www.camara.leg.br/proposicoesWeb/propmostrarintegra?codteor $=954987$ \&filename=PL+3036/2011. Acesso em 01 mar. 2019.

RISTUM, M. Bullying escolar. In: ASSIS, S.G. et al. (Orgs). Impactos da violência na escolar: um diálogo com professores [online]. Rio de Janeiro: Ministério da Educação/ FIOCRUZ, 2010, p.95-119. Disponível em: http://books.scielo.org/id/szv5t/pdf/assis-9788575413302-06.pdf Acesso em 19 mar. 2019.

ROCHA, H. Projeto de Lei No. 9243, de 2017. Câmara dos Deputados. Brasília, 2017. Disponível em: https://www.camara.leg.br/proposicoesWeb/propmostrarintegra?codteor $=1627532$ ffilename $=P L+9243 / 2017$ Acesso em 01 mar 2019.

ROLIM, E. Projeto de Lei No. 1841, de 2011. Brasília: Câmara dos Deputados, 2011. Disponível em: https://www.camara.leg.br/proposicoesWeb/propmostrarintegra?codteor $=899699$ \&filena-

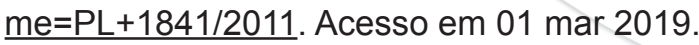

Projeto de Lei No. 2048, de
2011. Brasília: Câmara dos Deputados, 2011. Disponível em: https://www.camara.leg.br/proposicoesWeb/propmostrarintegra?codteor $=909678 \&$ filena$\mathrm{me}=\mathrm{PL}+2048 / 2011$. Acesso em 01 mar 2019.

SCHREIBER, Mariana. Brasil lidera índice internacional em número de partidos - o que isso significa para a crise?. BBC Brasil. Brasília. 29 Jun 2016. Disponível em: https://www.bbc.com/portuguese/brasil-36627957. Acesso em 25 mar. 2019.

SHÉRIDAN. Projeto de Lei No. 1671, de 2015. Brasília: Câmara dos Deputados, 2015. Disponível em: https://www.camara.leg.br/proposicoesWeb/propmostrarintegra?codteor $=1339374$ \&filename=PL+1671/2015. Acesso em: 01 mar. 2019.

- Projeto de Lei No. 3263, de 2015. Brasília: Câmara dos Deputados, 2015. Disponível em: https://www.camara.leg.br/proposicoesWeb/propmostrarintegra?codteor $=1397785$ \&filename=PL+3263/2015. Acesso em: 01 mar. 2019.

SILVA, Jorge Luiz da et al. Revisão sistemática da literatura sobre intervenções antibullying em escolas. Ciênc. saúde coletiva, v. 22, n. 7, p. 23292340, Jul. 2017. DOI http://dx.doi.org/10.1590/141381232017227.16242015. Disponível em: http:// www.scielo.br/scielo.php?script=sci arttext\&pi$\mathrm{d}=\mathrm{S} 1413-81232017002702329 \& \operatorname{lng}=e n \& \mathrm{nrm}=$ iso. Acesso em 19 mar. 2019.

TEIXEIRA, E. Projeto de Lei No. 3795, de 2015. Brasília: Câmara dos Deputados, 2015. Disponível em: https://www.camara.leg.br/proposicoesWeb/propmostrarintegra?codteor=1419154\&filena-

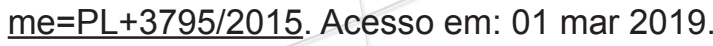

UOL. Autor do massacre no Rio sofreu bullying, dizem ex-colegas de escola. UOL Notícias. 08 abr. 2011. Disponível em: https://noticias.uol.com.br/cotidiano/ultimas-noticias/2011/04/08/autor-do-massacreno-rio-sofreu-bullying-dizem-ex-colegas-de-escola. htm. Acesso em 19 mar. 2019.

VIDIGAL, S. Projeto de Lei No. 7457, de 2010. Brasília: Câmara dos Deputados, 2010. Disponível em: https://www.camara.leg.br/proposicoesWeb/propmostrarintegra?codteor $=777693$ \&filena$\underline{m e}=P L+7457 / 2010$. Acesso em 01 mar 2019. 